\title{
Experiência, configuração e ação política: uma reflexão sobre as trajetórias do duque de Caxias e do general Osório
}

\author{
Adriana Barreto de Souza
}

Em 1976, ao escrever o prefácio à primeira edição de seu livro O queijo e os vermes, Carlo Ginzburg julgou que devia justificar sua opção por uma investigação capilar sobre as ideias e o cotidiano de um moleiro perseguido pela inquisição. Alguns estudos biográficos - afirmava Ginzburg - já mostraram que um indivíduo destituído de interesse por si mesmo pode ser pesquisado como sendo um microcosmo de um estrato inteiro, representativo de um grupo social ou de uma época. Mas, logo em seguida, indaga: seria este o caso de Menocchio? A resposta foi objetiva: "Nem por um sonho. Não podemos considerá-lo um camponês típico (no sentido de 'médio', estatisticamente mais frequente) do seu tempo: seu relativo isolamento na comunidade deixa isso claro." ${ }^{1}$

Investigar as ideias, crenças e ações de um indivíduo único, mais que os estudos biográficos - a história de um moleiro: era isso que precisava ser justificado. Nada era menos óbvio, com efeito, na prática historiográfica de então, quando equipes inteiras de estudiosos se lançavam em empresas imensas de história quantitativa ou de história serial. ${ }^{2} \mathrm{~A}$ análise de um destino individual implicava uma mudança de perspectiva decisiva, da qual o autor estava bastante ciente, e da qual, hoje, lhe somos devedores.

Passadas pouco mais de duas décadas, deparei-me com problema semelhante. Estudava a formação, as ideias e a atuação de indivíduo único - Luiz Alves de Lima e Silva, o duque de Caxias - e esta opção ditou uma série de escolhas referentes à maneira de abordar as fontes, e de como selecioná-las. ${ }^{3}$ Neste ponto, minha dívida para com as reflexões de Ginzburg é enorme. Refiro-me aqui, sobretudo, e mais especificamente, a um texto metodológico: "O nome e o como. Troca desigual e mercado historiográfico." ${ }^{4}$ Nele Ginzburg propõe o "nome” como uma espécie de bússola, capaz de cumprir um duplo papel: guiar o pesquisador pelo universo documental dos arquivos e organizar sua narrativa. Numa tal perspectiva, a trajetória de um único indivíduo pode se revestir de valor heurístico, ${ }^{5}$ como brecha de acesso ao passado, brecha através da qual é possível recompor e articular questões mais gerais, relativas a relaçôes familiares, a formação escolar/acadêmica, a estratégias de socialização e de a ação no mundo.

Mas se a dívida para com Ginzburg é evidente em meus textos, por outro lado, os objetos estudados são totalmente diferentes. Enquanto as desventuras de Menocchio podiam integrar um debate acadêmico importante, empenhado em romper o "silêncio das classes inferiores", buscando meios de "dar-lhes voz", meu objeto enfrentava outro "tabu historiográfico". Para além do desafio de construir uma narrativa historiográfica a partir da singularidade de uma vida, o indivíduo escolhido por mim era um "grande homem", um "homem de Estado", o que aumentava os riscos - já identificados por Ginzburg - de se cair na "famigerada 'história événementielle". ${ }^{6}$ Riscos tão temidos que, quase dez anos depois da primeira edição da história de Menocchio, durante um congresso na Sorbonne, ainda havia quem entendesse a biografia como abandono da "história-problema", como retorno a uma história cronológica e de conceituação frágil. ${ }^{7}$

A escolha por investigar a trajetória de um indivíduo único, no entanto, era no meu caso uma exigência dos rumos da pesquisa, das primeiras respostas que tinha obtido ao propor como problema, ainda durante o mestrado, uma reflexão sobre o lugar ocupado pelo Exército na política conservadora de consolidação do Estado imperial. ${ }^{8} \mathrm{O}$ modelo institucional a que cheguei, então, era inteiramente aberto, regido por valores e por um sistema de hierarquias amplos, os mesmos da sociedade política. O corpo de oficiais generais - como procurei mostrar em outra ocasião - era heterogêneo, herdeiro de uma tradição militar portuguesa estranha ao modelo moderno que associa a carreira à aquisição de conhecimentos técnicos específicos, à incorporação de valores orientados por uma disciplina rigorosa e a uma forte unidade 
corporativa. O único ponto comum ao grupo era a dependência da Coroa, que detinha o monopólio das patentes militares, podendo regular sua distribuição tal como fazia com outros bens simbólicos.'

Dada essa ausência de uma formação burocrática mais complexa e impessoal, o nível de formalização das trajetórias dos oficiais militares era baixo. Para se obter uma patente de general, havia vários caminhos possíveis, alguns dos quais sequer exigiam do pretendente experiência institucional, o que explica, por exemplo, um fenômeno comum até a década de 1850: a presença de homens de carreira notadamente política em postos de comando do Exército, distinguidos com altas patentes militares. ${ }^{10}$

Desse modo, era inviável propor uma abordagem sobre esse grupo social - os oficiais generais - a partir de prosopografias, da ideia de biografia representativa ou de estudos de caso. Nem o duque de Caxias, nem qualquer outro general poderiam ser considerados - parafraseando Carlo Ginzburg - militares "típicos no sentido de médios, estatisticamente mais frequentes". A heterogeneidade do grupo impedia a eleição da trajetória de um deles como trajetória-síntese, representativa de outras vidas, presentes no texto através de dados estatísticos. Recorrer a esta estratégia analítica, e a este uso do biográfico, implicaria ignorar - pior, negar - todo o esforço investigativo anterior.

Diante de tal diagnóstico, o que se definia, cada vez com mais precisão, era a necessidade de recusar o pressuposto de que o corpo de generais do Exército (ou o que seria pior, os "militares") constitui um grupo social a-histórico, que pode ser descrito antes que seja analisado o tecido das relações que o organiza e sustenta. ${ }^{11} \mathrm{O}$ problema é de formulação. Em lugar de considerar evidente a unidade e homogeneidade do grupo, impondo ao passado uma visão marcadamente moderna da carreira, é preciso inverter a perspectiva de análise e se interrogar sobre os valores e critérios a partir dos quais essa mesma carreira se organizava, sobre a experiência institucional dos atores sociais.

Foi assim que se desenhou o interesse pela biografia do duque de Caxias, e é assim que se desenha agora a proposta deste artigo. O objetivo é recorrer à trajetória do general Osório para, através de uma análise comparada, investigar outras experiências institucionais, ou, se preferirmos, outras formas de ser militar no Brasil do século XIX. Ou seja, a intenção não é ilustrar uma explicação mais geral a partir de novos dados, e sim tentarmos - para voltar a Ginzburg - aceder o passado por uma nova brecha.

Apesar de contemporâneos, o duque de Caxias e o general Osório nasceram e viveram em espaços geográficos, sociais, políticos e institucionais totalmente distintos. Destacar isso - que pode parecer óbvio - significa afirmar que as redes de dependência nas quais cada um deles se achava inscrito e o campo de possibilidades a partir do qual negociaram suas práticas como militares e realizaram suas escolhas eram também muito diversos. Todavia, isso não os impediu de construir uma carreira de sucesso: ambos chegaram ao posto de marechal do Exército, o topo da hierarquia militar, e ascenderam na nobiliarquia. Ainda que seja pouco lembrado, Osório foi agraciado pela monarquia com o título de marquês de Herval, o segundo maior título da nobiliarquia brasileira.

Antes de prosseguir, no entanto, vale explicitar o desnível que há em termos de pesquisa empírica na análise das duas trajetórias. A do duque de Caxias foi objeto de um minucioso trabalho sobre fontes, já para a análise da trajetória do general Osório, contei apenas com pesquisa em textos biográficos. $\mathrm{O}$ principal deles é a biografia escrita por seu filho, Fernando Luís Osório, publicada em 1893, quando a nascente república recuperou a memória do general para fazer dele o herói militar do novo regime. ${ }^{12}$

\section{O coronel e o lavrador: a travessia do Atlântico}

Quando em 1767 o coronel Francisco de Lima da Silva - tio-avô do futuro duque de Caxias - decidiu deixar a cidade de Faro, no Algarve, e seguir para o Rio de Janeiro comandando o Regimento de Bragança sob as ordens do tenente-general Johann Heinrich Böhm, agiu impulsionado pela mesma política que, na década anterior, havia estimulado a migração de jovens casais açorianos para o sul da América portuguesa. As duas ações - a colonizadora e a militar - buscavam fazer face ao que seria o maior desafio do reinado D. José I, que fora por sua vez herdado do reinado anterior, de D. João V: a delimi- 
tação das fronteiras portuguesas e espanholas na África, Ásia e, sobretudo, na América, região que em 1738 já era definida por D. Luís da Cunha, embaixador português em Paris, como central para a preservação econômica de Portugal. ${ }^{13}$

O Tratado de Madri (1750), último grande ato da administração de D. João V, ao substituir todos os atos anteriores, de Tordesilhas em 1494 a Utrecht em 1713, tentava assegurar o controle sobre as fronteiras através de uma política de ocupação efetiva do território sul das possessões portuguesas na América. Fundamentado no princípio do uti possidetis, o tratado colocou em curso um verdadeiro programa de povoamento. ${ }^{14}$ A estimativa é que de 31 de agosto de 1746 , data de publicação da resolução régia que anunciava a iniciativa, até 1754 , quando os últimos navios de imigrantes aportaram no litoral meridional do Brasil, foram enviados para a região cerca de 4.000 açorianos. ${ }^{15}$

Em um desses últimos navios, saído da Ilha de São Jorge com destino a Santa Catarina, vieram os bisavós paternos do futuro general Osório. Ao que parece tratava-se de um casal de agricultores, mas as informações são raras e pouco precisas. Aliás, nem o nome da bisavó do general é conhecido, e de seu marido só temos o primeiro nome: Pedro Luís. Para além disso, o que se sabe é que o casal decidiu instalar-se na Freguesia de Nossa Senhora da Conceição da Lagoa, situada na margem oeste da lagoa de mesmo nome (atual Lagoa da Conceição, em Florianópolis), e que o primeiro de seus filhos ganhou o nome do pai, Pedro Luís. Dando sequência à trajetória da família, Pedro Luís filho casou-se com Maria Rosa, jovem nascida na mesma freguesia e, tal como ele, filha de açorianos. Juntos, o casal seguiu dedicando-se à lavoura e, desta união, nasceram várias crianças, tendo sido a primeira delas um menino, batizado Manoel Luís. ${ }^{16}$

Manoel Luís - que viria a ser o pai de Osório - nasceu na mesma Freguesia de Nossa Senhora da Conceição da Lagoa, em 1777. Era um ano especialmente difícil para os moradores da região. Desde fevereiro, Santa Catarina estava sob domínio das forças espanholas de Dom Pedro de Cevallos, que, da ilha, tentavam conquistar a capitania do Rio Grande. Apesar de a invasão só ter ocorrido naquele ano, a população achava-se mobilizada para a guerra desde 1761, quando o colapso do Tratado de Madri provocou uma grande ofensiva espanhola para expulsar os portugueses da Colônia do Sacramento (que pelo tratado ficaria com os espanhóis) e das terras por eles povoadas, de Santa Catarina até as cobiçadas pastagens e pradarias do interior da capitania do Rio Grande. ${ }^{17}$

Vivendo numa região em franca disputa, cujo povoamento era parte da estratégia portuguesa de conquista, é difícil imaginar que Pedro Luís - o avô do futuro general Osório - não tenha, ao longo de sua vida, integrado uma força miliciana e lutado nas várias batalhas ocorridas na fronteira. Todavia, se não o fez, colocou seu filho cedo no serviço das armas. Em 1793, aos 16 anos de idade, Manoel Luís entrou para a carreira como soldado, tendo passado no ano seguinte a cabo, e, três anos depois, a furriel. ${ }^{18}$

Ao que tudo indica, Manoel Luís servia em uma força local, da própria freguesia de Nossa Senhora da Conceição da Lagoa, mas a experiência foi curta. Ainda furriel, Manoel Luís foi preso após ter reagido ao insulto de um capitão, rebatendo seu golpe de espada com a alabarda que empunhava. Quem conta o episódio é seu neto-biógrafo, mas independentemente do que possa ter ocorrido, o fato é que Manoel Luís foi preso e, três dias depois, fugiu da prisão, seguindo em direção à capitania do Rio Grande. Quando chegou à freguesia de Nossa Senhora da Conceição do Arroio, estava - ainda é seu neto quem conta - "esfarrapo, faminto e extenuado pela fadiga". Buscando trabalho, bateu à porta do tenente Tomás José Luís Osório, que o abrigou como peão em suas lavouras. Meses depois, o peão desposava a filha mais nova do tenente, Ana Joaquina. ${ }^{19}$

Osório, portanto, é a linha materna da família do futuro general, que na verdade foi o terceiro dos dez filhos deste matrimônio. Apenas seu primeiro nome homenageava o pai, que, tendo recebido por ocasião de seu casamento e - segundo o neto-biógrafo - "por equívoco" o sobrenome Silva Borges, decidira presentear o "sogro que lhe acolheu na desgraça", perpetuando o sobrenome da família. Daí, Manoel Luís Osório. ${ }^{20}$

Ao escrever sobre os Osório, os biógrafos localizam sua origem na nobreza de Espanha. Mas a informação não é devidamente comprovada. A única fonte utilizada, até pelo biógrafo da família, é o livro 
do visconde de Saches de Baena, intitulado Arquivo Heráldico Genealógico, e reconhecidamente insuficiente para este tipo de pesquisa. Por outro lado, ao tentar enraizar historicamente esses laços de um passado remoto, perdido na Idade Média ibérica, o mesmo biógrafo recupera a história de dois irmãos militares, que teriam deixado Portugal ainda na primeira metade do século XVIII para lutar na fronteira sul da América portuguesa. As informações são fragmentadas, porém mais plausíveis. Tomás Luís Osório e José Luís Osório, naturais do arcebispado de Lisboa, tendo atravessado o Atlântico para combater os espanhóis, decidiram se estabelecer no Rio Grande, casando-se com descendentes de açorianos, adquirindo estâncias e fazendo carreira nas forças milicianas. Tomás, mais que José Luís, dedicou-se à carreira militar. Participou de todas as grandes campanhas da região, inclusive da Guerra Guaranítica, o que lhe rendeu o alto posto de coronel do Regimento de Dragóes do Rio Pardo. ${ }^{21}$

Foi nesta família que Manoel Luís ingressou ao se casar com Ana Joaquina. O pai da jovem, o tenente Tomás Luís, era filho de José Luís Osório, e dava continuidade à tradição da família quando Manoel Luís bateu à sua porta. Administrava suas terras e servia nas forças milicianas rio-grandenses, caminho que a partir de então seria trilhado também por Manuel Luís, que assumia o nome, falso ou não, de Silva Borges.

Apesar de o Tratado de Santo Ildefonso (1777) ter sustado os grandes combates entre as coroas ibéricas, os pequenos conflitos de fronteira persistiam. Durante a década de 1790, por exemplo, houve na fronteira sul vários desses conflitos que, na linguagem militar, são denominados "incidentes fronteiriços". ${ }^{22}$ A mobilização oficial, contudo, só voltou a ocorrer em 1811, quando o governo de Buenos Aires se declarou independente da Espanha e instalou uma junta governativa com a intenção de libertar toda a região do Prata. A resposta de D. João foi pronta. Temendo que o movimento se estendesse para o sul do Brasil, e acionado pelo governador de Montevidéu, que se manteve fiel à coroa espanhola, o príncipe regente determinou que um "exército de observação" - logo em seguida rebatizado "exército pacificador" - entrasse em território uruguaio. ${ }^{23}$

Mais amadurecido, casado e com pelo menos três filhos pequenos para criar, tão logo soube da notícia, Manoel Luís da Silva Borges decidiu retomar sua vida militar e apresentou-se voluntariamente a uma companhia de milícias. Como esta se achava sem comandante, Manoel Luís, mesmo sendo apenas um furriel - que corresponderia hoje a sargento - foi alçado a seu comando, partindo para Montevidéu em 1811. De lá, voltaria condecorado e elevado ao posto de capitão. Quatro anos depois, voltava oficialmente a campo para lutar na campanha de 1816, na qual a coroa portuguesa expressava, agora sem subterfúgios, o interesse em expandir as fronteiras, anexando a Província Oriental. Os serviços então prestados pelo capitão Manoel Luís, em defesa desses interesses na fronteira, lhe renderam mais uma promoção, dessa vez, ao posto de major. ${ }^{24}$

Mas o envolvimento em todas essas guerras, ou nos "incidentes fronteiriços", à frente das milícias, não rendia a esses homens apenas patentes e condecorações. Em 1812, ao fim das operações na Banda Oriental, largas faixas de terra da região de Entre-Rios foram oficialmente ocupadas através da doação de sesmarias aos militares que tinham lutado na guerra. ${ }^{25}$ Ao fazerem a campanha para o rei de Portugal, esses homens expandiam suas propriedades, avançando sobre terras mais férteis e se assenhoreando de grandes rebanhos de gado. Aliás, entre 1817 e 1825, quando se dá o domínio efetivo da região, muitos deles levaram para o novo território capital para comprar terras e gado, trazendo ainda grandes manadas para suas estâncias no Rio Grande do Sul. ${ }^{26}$

Esse tipo de movimento gerou uma cultura militar específica nesta região, a do soldado-estancieiro. ${ }^{27}$ O major Manoel Luís, por exemplo, após a campanha de 1816, foi nomeado comandante da linha do Uruguai. O exercício do posto no novo território permitiu-lhe requerer junto ao imperador para ser agregado ao seu Regimento como tenente-coronel, mas também lhe permitiu, através da estreita relação que mantinha com o governador de Armas dessas terras, o duque de Saldanha, pensar em uma sociedade. O negócio, ao final, parece não ter dado certo. Mas Manoel Luís empregou parte de seu capital na compra de couro com o objetivo de exportar a mercadoria para a Europa. ${ }^{28}$ 
Nessa cultura do soldado-estancieiro se formariam gerações de militares do sul, homens que aprenderam a associar a carreira à aquisição de terras e gado. Para além dos Osório, família de milicianos com tradição nas guerras de fronteira, é possível citar ainda o nome de dois dos futuros líderes farroupilhas, que fizeram fortuna cruzando essas linhas, ainda bastante móveis - David Canabarro e Bento Gonçalves. ${ }^{29}$

Servir nas milícias do Rio Grande era defender esses interesses e trabalhar por sua expansão. Uma cultura militar vinculada às particularidades da região e, portanto, totalmente distinta daquela em que se formariam os Lima da Silva. Diferentemente dos antepassados paternos de Osório, os de Caxias vieram de Portugal, logo, do centro do Império, para o Rio de Janeiro, capital do Vice-Reino do Brasil. Além disso, Francisco de Lima da Silva, bem como seu irmão caçula, José Joaquim, tinham uma vinculação institucional bem definida - eram oficiais dos Exércitos Reais. Mesmo não sendo fidalgos, nem pertencendo a uma família de cabedal, chegavam à América portuguesa em condições bem diferentes dos "Silva Borges". Para começar, tinham um nome. O fato de Manoel Luís - o pai de Osório - não ter dado seu nome aos filhos e, pior, ter aceitado um nome que lhe fora atribuído "por equívoco" é indicativo de uma existência sem tradição, ou de um passado a ser ocultado. Em ambos os casos, tratando-se de uma sociedade de Antigo Regime, esse era um destino duro, quase perdido.

Francisco de Lima da Silva, ao contrário, chegava ao Rio de Janeiro em 1767 no prestigioso posto de coronel do Regimento de Bragança, integrando uma expedição militar comandada por um oficial da renomada "escola prussiana", o tenente-general Böhm. Nascido em Lagos, no Algarve, região ao sul de Portugal, o então coronel Lima da Silva era o que se chamava na época de "oficial prático". ${ }^{30}$ Tendo assentado praça aos 18 anos como alferes, serviu em cada um dos postos da carreira, sendo promovido de forma gradativa, em função dos serviços militares prestados à Coroa portuguesa.

O fato de não ter ingressado na carreira militar como soldado, tal como Manoel Luís da Silva Borges, é um indicativo de que, apesar de não pertencer a uma tradicional família do Reino, Francisco de Lima - como o oficial ficaria conhecido - devia integrar alguma rede clientelista local, fundada em laços de parentesco e amizade. Essas redes, no entanto, tinham seus limites. O clientelismo podia explicar o ingresso de um jovem no Exército como alferes, só que dificilmente bastaria para levar um alferes à patente de coronel, e depois a brigadeiro, como se deu com Francisco de Lima. O elemento que acredito ter sido um diferencial nessa ascensão, catalisando possíveis influências da família ou de um apadrinhamento, foi a decisão, tomada em 1740, quando ainda era um jovem tenente, de deixar sua terra natal para se lançar em uma expedição militar às Índias Orientais. Duas das promoções recebidas por Francisco, que lhe garantiram as patentes de capitão e de sargento-mor, ao que parece, ocorreram em meio às campanhas de defesa das praças de Goa e Alorna. ${ }^{31}$ De volta a Portugal, o então sargento-mor seria beneficiado pelas reformas implantadas no Reino pelo mais novo Secretário de Estado da Guerra e Negócios Estrangeiros, o futuro marquês de Pombal. Preocupado em conter todas as formas de contestação à autoridade central, principalmente o antiabsolutismo da nobreza, o secretário tentava ampliar as bases políticas do governo, nomeando para os postos de comando do Exército oficiais sem origem nobre e favorecendo, por meio da criação do título de cadete, o ingresso de filhos de oficiais militares na carreira. ${ }^{32}$

Os dois irmãos Lima da Silva seriam favorecidos por essa política. Francisco foi promovido em 1757 a tenente-coronel, e, com entrada de Portugal na Guerra dos Sete Anos, chegou a coronel. Já seu irmão caçula, José Joaquim, ingressou na carreira, tal como Manoel Luís "da Silva Borges", ao completar 16 anos de idade, mas com duas diferenças: ingressou no Exército e usufruindo o prestígio da distinção de cadete.

Ao título de cadete, retornarei mais adiante. Por ora, gostaria de destacar apenas que a carreira do mais velho dos Lima se construiu a partir da experiência adquirida ao longo de sua vida, como oficial do Exército Real, em expedições militares no ultramar e em guerras na Europa. Daí a definição de "oficial prático". Era deste ofício que tirava seu sustento, e nele é que investia mais uma vez ao decidir, após o falecimento de seus pais e a desmobilização das forças de guerra, embarcar na expedição do tenente-general Böhm, levando com ele o irmão 29 anos mais moço, o jovem José Joaquim. 
Sua estada no Brasil, porém, acabou sendo uma experiência melancólica. Para além do tombo que tomou ainda na nau da Ajuda, quando fazia a travessia do Atlântico, e que o deixou inutilizado para o serviço durante os primeiros meses em terra, Francisco de Lima, ao que parece, também teve dificuldades de se adaptar ao sistema disciplinar do tenente-general Böhm, o que o levou a perder o controle sobre a tropa. Tudo isso para, ao final, ver o Império perder a guerra contra os espanhóis e, com ela, a Província da Cisplatina. Mas apesar de um balanço tão negativo, o então coronel foi devidamente remunerado. A Coroa sabia que não era possível manter a "boa ordem" de um governo sem prêmios e punições. Esse princípio é que firma as monarquias de Antigo Regime. ${ }^{33}$ Francisco de Lima não poderia retornar a Portugal, após dedicar dez anos de sua vida ao Império, sem receber algum tipo de benefício. Além do governo de Castro Marim, no Algarve, regiáo de onde partira em 1767, ele também foi promovido a brigadeiro. ${ }^{34}$

Ainda jovem, José Joaquim de Lima da Silva até então não tinha colhido bons benefícios com a expedição militar de Böhm, e talvez por conta disso tenha decidido permanecer no Brasil. Mas também enfrentaria dificuldades. Capitão do regimento de Bragança, jovem, solteiro e vivendo em uma cidade que não era a sua, depois de 1779 , José Joaquim não podia nem mais contar com a preciosa ajuda do irmão, há dois anos oficial-general, fidalgo da Casa Real, e governador de uma praça militar do Reino. Francisco de Lima tinha morrido. ${ }^{35}$ Como se não bastasse, após a guerra no sul contra os espanhóis, nenhuma outra oportunidade se abriu para os militares que serviam no Rio de Janeiro. Ou seja, a ascensão de José Joaquim na carreira, diferente do que ocorrera com o irmão, foi lenta. ${ }^{36} \mathrm{O}$ menor tempo de espera por uma promoção foi de sete anos, pela patente de capitão, concedida pouco antes de seu embarque para o sul. Para passar a sargento-mor (atual major), que lhe daria acesso ao corpo de oficiais-superiores do Exército, José Joaquim teve que esperar por quinze anos e, pela patente de tenente-coronel, esperou outros onze anos. Diferente do irmão, que ascendeu ao posto aos 40 anos de idade, José Joaquim contava 54 anos quando foi promovido a tenente-coronel.

$\mathrm{Na}$ tentativa de obter uma melhor colocação nos serviços da Coroa e ampliar seus vínculos sociais no Rio de Janeiro, em 1785, José Joaquim de Lima se casaria com Joana Maria da Fonseca Costa, ${ }^{37}$ de uma família estabelecida na cidade desde o século XVII e tipicamente militar, com vários de seus membros ocupando postos nas forças de linha e entre os auxiliares. ${ }^{38}$ Mas o desencanto de José Joaquim de Lima com a falta de oportunidades na carreira era de tal ordem que, para tentar uma melhor colocação na sociedade, o então sargento-mor decidiu procurar um posto fora do Exército. Depois de mais de 35 anos de dedicação à Coroa como militar, parecia desistir, e tentava ingressar na carreira de homem público. Requeria a "propriedade" de um dos ofícios vagos na cidade, e os listava: "São os de escrivão da ouvidoria geral do civil, de inquiridor, contador e distribuidor-geral, de escrivão da Coroa e o de tabelião de notas." 39

Infelizmente, não foi possível saber se José Joaquim de Lima foi bem-sucedido nessa investida. Mas, ao que parece, ele não desistiu de seu projeto de ascensão social. Frente às dificuldades, tentava o caminho mais simples para se alcançar certa distinção em sociedades de Antigo Regime: procurava expandir suas relações sociais, sobretudo as familiares. ${ }^{40}$ Com cinco filhos em 1800 , José Joaquim nunca deixou de investir em sua descendência, fosse através da contratação de bons casamentos, fosse aumentando a presença da família Lima no $1^{\circ}$ Regimento de Infantaria do Rio de Janeiro, nome do antigo Regimento de Bragança, e onde José Joaquim continuava servindo.

Esse projeto de ascensão social, no entanto, teria caminhado timidamente se não fosse a chegada em 1808 da corte portuguesa ao Rio de Janeiro. Até então, mesmo com tanto esforço, José Joaquim ainda era apenas um tenente-coronel. Mas em novembro de 1808, foi graduado coronel e, num curtíssimo prazo um ano e sete meses, o menor de sua carreira - saía sua efetividade no posto. Finalmente, ocupava a vaga que havia sido de seu irmão, tornando-se coronel do $1^{\circ}$ Regimento de Infantaria do Rio de Janeiro. ${ }^{41}$

A rapidez dessas promoções resultava das alterações efetuadas na organização militar da capital para acolher a corte recém-chegada. Oliveira Lima considera que "o reinado de D. João foi o único período de imperialismo consciente que registra a nossa história". ${ }^{42}$ De fato, nesse período, a monarquia reanexou a 
Guiana Francesa, de que Portugal abrira mão no Congresso de Viena, e a estratégica Cisplatina, tão disputada na fronteira sul da América portuguesa. Se a ausência de campanhas militares das décadas anteriores havia impedido a promoção de José Joaquim de Lima no Exército, o contexto agora se tornava favorável, principalmente se lembrarmos que, além dessas conquistas empreendidas por D. João VI, havia ainda a chance de integrar uma expedição militar destinada a reprimir revoltas como a de 1817, em Pernambuco. Assim, após passar toda sua vida aguardando por anos uma promoção, José Joaquim, com apenas dois anos de serviço no posto de coronel, foi promovido em 1812 a brigadeiro dos Exércitos Reais.

A dinâmica dessas operações de guerra promovia uma circulação inter-regional bem interessante para os oficiais militares. O segundo filho do brigadeiro José Joaquim de Lima da Silva, que herdara seu nome, recebeu em dezembro de 1814 uma promoção para sargento-mor como prêmio por ter assumido o cargo de inspetor de milícias do Piauí. Três anos depois, quando retornou à corte, já era tenente-coronel. O fato de ter aceitado se deslocar para uma capitania distante, e lá ficar por tanto tempo, permitiu que o jovem oficial fosse agraciado com a patente antes de seu irmão mais velho, Francisco de Lima da Silva, que só a obteve cinco meses depois, em julho de $1818 .{ }^{43}$

Apesar da espera, Francisco de Lima levava uma vantagem sobre o irmão - tornava-se tenente-coronel do 1ํㅡㄹ Regimento de Infantaria do Rio de Janeiro, assumindo um posto que havia sido de seu pai e que, por isso, o mantinha na posição de dar continuidade à tradição da família. Vale lembrar mais uma vez que esse regimento equivalia ao antigo Regimento de Bragança, que chegou ao Rio de Janeiro em 1767, na expedição do tenente-general Johann Heinrich Böhm. O coronel que primeiro exerceu seu comando foi o português Francisco de Lima da Silva, tio já falecido do agora tenente-coronel do mesmo nome. Seguindo a tradição portuguesa, o regimento seria informalmente batizado com o nome da família, tornando-se o "regimento dos Lima". ${ }^{44}$

Os anos de 1817 e 1818 coroaram a carreira do brigadeiro José Joaquim de Lima da Silva. Em setembro de 1817, ele foi agraciado com o prestigioso hábito da Ordem de Cristo e, no ano seguinte, após ter sido graduado marechal de campo, recebia a mercê de fidalgo cavaleiro da Casa Real. ${ }^{45}$ No espaço de uma década, em razão das mudanças político-militares operadas na cidade com a transferência da corte, a carreira e a vida do velho oficial conheceram mudanças impensáveis até o início do século. Aos 72 anos de idade, o marechal Lima via realizado seu desejo de ascensão social - ingressava nos círculos mais próximos ao rei. ${ }^{46}$ Sabia, porém, que sua tarefa não estava encerrada. Para sedimentar sua nova posição era preciso também reposicionar socialmente a família. Se antes já tratava com grande zelo a carreira dos filhos, agora que desfrutava de suficiente capital político, se dedicaria integralmente a ela. Sua primeira intervenção foi a favor do terceiro filho, o capitão Manoel da Fonseca de Lima da Silva. O jovem oficial recebia, aos 25 anos, o hábito de Cristo, em atenção a um requerimento de seu pai. Certamente, ao escolher Manoel da Fonseca, o marechal levava em conta sua idade avançada. Ainda no início da carreira, o rapaz era, dos filhos mais velhos, o que menos condiçóes teria de se posicionar na corte caso o pai viesse a falecer nos próximos anos.

A partir daí, tem início um curioso jogo de administração de mercês. Em 1819, D. João, em nova demonstração de sua "real munificência", concedeu mais um benefício ao marechal de campo José Joaquim de Lima "pelos seus bons serviços praticados" - ele era agraciado com "uma vida a mais na comenda de São Bento de Aviz". Isso significa que poderia passar a mercê a um de seus descendentes, e o escolhido - seguindo agora a tradição - foi seu primogênito, Francisco de Lima. Em seguida, foi a vez do segundo filho - José Joaquim. Ele recebeu, também em 1819, o foro de fidalgo cavaleiro da Casa Real com "todas as honras e direitos". Enquanto o pai o tinha obtido "por sua patente", o filho era agraciado "por honra de seu pai". ${ }^{47}$

A presença da Coroa portuguesa favorecia o enraizamento de uma cultura de Antigo Regime no Rio de Janeiro, fundada, como no Reino, em uma "economia de favores". ${ }^{88}$ Quando o marechal de campo José Joaquim de Lima morreu em 1821, parte da família havia completado sua metamorfose e seus filhos mais velhos se apresentavam como nobres. Francisco de Lima, ao ser promovido coronel, assumiu 
o comando do $1^{\circ}$ Regimento de Infantaria da cidade com a comenda de São Bento de Aviz. José Joaquim de Lima era tenente-coronel do mesmo regimento com o foro de fidalgo cavaleiro da Casa Real. O jovem capitão da família, Manoel da Fonseca de Lima, contava em sua fé de ofício ${ }^{49}$ com um serviço em Pernambuco - na repressão à revolução de 1817 - e era habilitado pela Ordem de Cristo. No entanto, além deles, o marechal José Joaquim deixava dois outros filhos oficiais - João Manoel de Lima da Silva e Luís Manoel de Lima da Silva. Ambos eram ainda bem jovens. João Manoel tinha 16 anos e Luiz, 15. Mas os dois já integravam o, agora tradicional, "regimento da família".

Sepultado no convento de Santo Antônio, honraria destinada somente à nobreza local, o marechal José Joaquim de Lima da Silva, que chegara à cidade ainda rapaz, havia transformado sua história e a de sua família. ${ }^{50} \mathrm{O}$ pacto político sobre o qual se mantinha o Império português criava um sistema atraente que, através de negociações cotidianas, realizadas entre diferentes níveis hierárquicos (por isso, marcadas pela desigualdade), conseguia garantir que princípios e valores aristocráticos entalhassem a vida social na América, incluindo aí as instituições militares, até mesmo o Exército.

\section{Um cadete na corte, e outro na fronteira}

Luiz Alves de Lima e Silva - o futuro duque de Caxias - era neto do marechal José Joaquim de Lima, e filho de seu primogênito Francisco de Lima. Quando nasceu, em 25 de agosto de 1803, seu avô ainda lutava com dificuldades para obter a patente de coronel, e o pai era um jovem capitão do 1ำ Regimento de Infantaria do Rio de Janeiro. Com apenas 18 anos de idade, Francisco tinha se casado dois anos antes, em novembro de 1801, com Mariana Cândido de Oliveira Belo. Conhecidos no Rio de Janeiro, os Oliveira Belo também tinham tradição como militares, mas nas forças auxiliares, o que os tornava mais influentes na cidade e lhes rendia boas relaçôes no governo.

Neto primogênito das duas famílias, Luiz Alves nasceu na fazenda de seu avô materno, coronel de quem herdara o nome - Luiz Alves de Freitas Belo. Foi também nessa propriedade, situada no fundo da Baía de Guanabara, na freguesia de Inhomirim (atual município de Magé), que o menino cresceu. Por razões diferentes, que em nada lembravam a trajetória dos Lima, esse também era um momento delicado na vida dos Oliveira Belo, que tentavam se reposicionar socialmente no Rio de Janeiro. ${ }^{51}$ Pelos dois lados, portanto, a família procurava proteger seus descendentes, acionando e fazendo uso das distinções a que tinha direito. Foi assim que, seguindo a tradição dos Lima, iniciada por seu avô, e mantida por todos os tios, Luiz Alves assentou praça no Exército como cadete. A diferença estaria na idade. A distinção lhe foi conferida aos 5 anos e, ainda que fosse apenas simbolicamente, o menino iniciava sua vida militar no "regimento da família", no 1ํo Regimento de Infantaria do Rio de Janeiro.

O título de cadete havia sido criado em 1757 como parte da política reformista do marquês de Pombal, e afirmava o interesse da Coroa portuguesa de que a nobreza de seu Reino tivesse "escolas próprias para se instruir nas artes e disciplina militares". ${ }^{52}$ Para atrair essa nobreza, avessa ao serviço militar sistemático, o rei favorecia o ingresso de seus filhos no Exército, concedendo-lhes uma nova distinção.

A medida era intervencionista e tinha o objetivo de amenizar, através de um investimento de longo prazo, os problemas gerados por um oficialato composto por homens que, na sua maioria, não faziam ideia do que significava subordinação. Nesse ponto, vale observar o termo "escola". Ele não se refere à criação de uma instituição de ensino, formalmente organizada. A proposta é mais ampla, refere-se a um conjunto de princípios pautados na subordinação. $\mathrm{O}$ próprio processo de aquisição do título, que exigia do requerente o cumprimento de uma minuciosa burocracia, incluindo aí o exame e validação de todos seus atestados de nobreza, já constituía em si um exercício de subordinação de tradicionais famílias ao Estado. ${ }^{53}$ Porém, o que mais interessa aqui é um outro aspecto desta medida - a intenção de estimular o ingresso no Exército Real dos filhos de oficiais de linha e de oficiais dos terços auxiliares. Neste caso, a única exigência era a de que fossem filhos de oficiais de patente. Para os oficiais do Exército, a patente mínima exigida era a de sargento-mor, e para os oficiais dos terços auxiliares era a de coronel. A distinção iguala- 
va, assim, filhos de nobres e de oficiais militares. Na prática, estes ainda tinham uma vantagem: não precisavam se submeter ao processo de comprovação de nobreza. Para eles, bastava o registro de batismo.

Em maio de 1797, no entanto, uma nova lei eliminou a idade mínima de 15 anos para se requerer o título de cadete, e foi desse modo que Luiz Alves, tal como seus tios mais novos, pode obter a honraria aos 5 anos. Ela representava um ingresso simbólico na carreira militar, que só se efetivaria quando o jovem completasse 15 anos de idade. Neste momento, o título, adquirido a partir de critérios de nascimento, começava a interferir de forma bem nítida no desenho hierárquico do Exército. $\mathrm{O}$ jovem cadete não precisava passar pelos postos inferiores, de furriel a primeiro-sargento. Ele ingressava direto como alferes, primeira patente do corpo de oficiais subalternos. ${ }^{54}$

Em princípio, esse é um ponto comum à trajetória de Luiz Alves de Lima e à de Manoel Luís Osório. Ambos assentaram praça no Exército como cadete. Mas apesar de terem sido distinguidos com o mesmo título, e, desse modo, ingressado no Exército com a mesma patente (alferes), a posição que ocupavam na instituição era distinta. Enquanto Luiz Alves atualizava a herança da família, representando a terceira geração dos Lima a ser distinguida com o título, Manuel Luís era o primeiro, tanto na linha materna quanto na paterna, a se tornar cadete. E, ainda assim, em circunstâncias muito especiais.

Quando Manoel Luís Osório nasceu, no dia 10 de maio de 1808, seu pai ainda não tinha retomado a vida militar, e prosseguia trabalhando na estância de seu sogro, Tomás José Luís Osório. ${ }^{55}$ A prisão e enforcamento de um tio de Tomás José, um dos dois irmãos Osório que fizeram a travessia do Atlântico, um coronel de milícias com prestígio da região e "muito elogiado pelo vice-rei Gomes Freire de Andrade", ${ }^{56}$ parece ter deixado marcas na família. Tomás José Luís Osório, avô de Manoel Luís, não investia na carreira militar, e quando o neto nasceu, exercia o mesmo posto no qual sete anos depois, em 1815, se reformaria, o de tenente de milícias. Desse modo, Manoel Luís não tinha direito ao título de cadete e, mesmo depois, com o retorno do pai à carreira militar, permanceria sem acesso à distinção. A patente do pai ainda não era suficiente para distinguir o filho. Por isso, pouco antes de completar 15 anos de idade, Manoel Luís assentou praça voluntariamente na Cavalaria da Legião de São Paulo. O rapaz só obteve o título de cadete no ano seguinte, em 1824, quando um tio, o tenente-coronel Tomás José da Silva, assumiu o comando do $3^{\circ}$ Regimento de Cavalaria do Exército. Na $2^{\underline{a}}$ companhia deste regimento, sob a tutela do tio, o jovem Manoel Luís Osório, aos 16 anos, era reconhecido cadete e ingressaria como alferes nas fileiras do Exército Real.

Mas a vida militar, fosse a das milícias ou a do Exército, não agradava a Manoel Luís Osório. Todos os biógrafos, inclusive seu filho, afirmam que o jovem só assentou praça "para ser agradável a seu pai" e que, na "primeira vez em que este lhe falou em tal, derramou lágrimas" ${ }^{57}$ Um início de carreira totalmente diferente da de Luiz Alves de Lima, cuja tradição familiar o destinou desde a mais tenra idade para o Exército, vinculando-o então, mesmo que simbolicamente, ao regimento no qual seu avô tinha construído uma carreira de sucessos - o 1ำ Regimento de Infantaria do Rio de Janeiro.

Já o desejo de Manoel Luís era estudar. Ainda que os biógrafos não informem a carreira pretendida pelo rapaz, todos apontam o esforço de seu pai para convencê-lo de que ali, no Rio Grande, não conseguiria obter "instrução de valor". Até 1820 , não havia aulas públicas de primeiras letras na capitania ${ }^{58}$ e, sendo assim, a formação de Manoel Luís tinha sido muito limitada. Primeiro, iniciou seus estudos na única escola da região, uma escola particular cujas aulas eram ministradas por um sapateiro. Depois, passou a ter aulas em casa, com seu padrinho e, só em 1821, Manoel Luís, então com 13 anos de idade, conseguiu frequentar uma escola particular de primeiras letras mais organizada, dirigida pelo capitão de dragões Domingos José de Almeida. A escola ficava em Salto, cidade da Província Oriental, e seu ingresso nela deveu-se à anexação do território pela Coroa portuguesa em 1821. Com a anexação, o pai do rapaz, o major Manoel Luís da Silva Borges, foi destacado para a guarnição de Salto, e levou consigo a família. Só então, o jovem Osório começou a adiantar seus estudos e - segundo seus biógrafos - a tomar gosto por eles. ${ }^{59}$ Mas a experiência foi curta, logo interrompida pela notícia da Independência do Brasil que, convulsionando a região, arrastou militares das milícias e das tropas de linha para a guerra. Silva Borges, 
na época tenente-coronel, foi convocado a integrar as forças fiéis a D. Pedro e foi então que decidiu que era hora de Manoel Luís conhecer a vida militar, levando-o "junto a si para o serviço das armas". ${ }^{60}$

O ingresso de Manoel Luís Osório nas forças milicianas e, logo em seguida, no Exército Real deuse, portanto, em um contexto de guerra. Deixou Salto para incorporar as forças do general Carlos Frederico Lecor que, encarregado do governo da Província Oriental, enfrentava em Montevidéo a resistência de D. Álvaro da Costa Macedo, oficial português que servia sob suas ordens no cargo de ajudante general. Não reconhecendo o decreto que desligava a Divisão Lusitana, estacionada em Montevidéo, do Exército de Portugal, D. Álvaro da Costa sublevou soldados e oficiais portugueses, tomou o governo civil e militar da porvíncia, e obrigou o general Lecor a se retirar para a Campanha. Era o início das "Guerras de Independência" no sul da América portuguesa. ${ }^{61}$

O argumento do tenente-coronel Silva Borges para convencer seu filho, o jovem Osório, a deixar os estudos em Salto e seguir para a guerra foi o mesmo que levara Luiz Alves de Lima, na mesma época, a abandonar o curso da Real Academia Militar no Rio de Janeiro: "No tempo das agitaçóes que se viviam, num país em que faltavam mestres (...) outra porfissão não havia, mais nobre e gloriosa, do que a militar." ${ }^{\prime 2}$

Cinco anos mais velho que Manoel Luís Osório, em 1822 Luiz Alves era tenente do 1o Regimento de Infantaria do Rio de Janeiro. Inicialmente, sua formação havia se dado na fazenda São Paulo, junto à sua avó Ana Quitéria. Depois, ao que parece, cursou o Seminário São Joaquim. Esses anos iniciais de sua vida, porém, permanecem meio obscuros. Só há notícias mais precisas sobre a trajetória escolar de Luiz Alves a partir de 1818, quando entrou para Real Academia Militar - uma das novidades implantadas no Rio de Janeiro com a chegada da corte portuguesa em $1808 .{ }^{63}$

Mas até esse momento, a origem social das famílias Lima e Osório ainda não tinham se traduzido em favorecimentos no Exército. Considerando a diferença de idade entre os dois oficiais, era esperado que Luiz Alves já tivesse obtido uma promoção, e fosse agora um tenente. $\mathrm{O}$ que alargou o campo de possibilidades do jovem Lima, e o favoreceu, foi a inserção político-social da família. O rapaz que se matriculou na Real Academia Militar era o neto mais velho de um marechal de campo do Exército Real que, por serviços prestados, fora agraciado poucos meses antes com o prestigioso hábito da Ordem de Cristo. No primeiro ano letivo, seu pai, Francisco de Lima, tornou-se tenente-coronel do regimento no qual Luiz Alves servia como cadete, e a família dava início à sua metamorfose em nobres. ${ }^{64}$ Isso em função da atuação de seus tios, pai e avô nas campanhas militares realizadas pela Coroa no sul, em Caiena e em Pernambuco.

Essa inserção político-militar dos Lima tornava quase pessoal a vinculação de Luiz Alves ao regimento. Quando precisou, em novembro de 1817, de um documento atestando sua participação na cerimônia de "desembarque de Sua Alteza Real a Princesa Real", integrando a Guarda de Honra, dirigiu um ofício, junto com outros oficiais, ao brigadeiro "do regimento de infantaria José Joaquim de Lima e Silva", seu avô. ${ }^{65}$ A atestação foi logo emitida e certamente a inclusão de seu nome na lista dos oficiais que participariam da Guarda de Honra devia-se aos mesmos laços familiares. Esse é um traço dos exércitos de Antigo Regime: as "famílias mais fortes geriam a aprendizagem militar de seus filhos e consideravam o regimento um prolongamento da autoridade paterna". ${ }^{66} \mathrm{Na}$ definição da posição social dessas famílias - portanto, de sua "força" - um elemento decisivo era o quanto estavam próximas da Coroa, que detinha o monopólio de distribuição dos bens simbólicos, incluídas aí, as patentes militares.

Essa porosidade hierárquica, que cruzava a carreira militar com a política, e promovia o estreitamento de vínculos com a Coroa, fica evidente no decreto de 13 de maio de 1789 . Por ele, todos os oficiais que subissem aos postos de marechal de campo ou tenente-general, mesmo os que não tivessem assentado praça de cadete, se tornavam automaticamente fidalgos da casa real. Além disso, e reforçando essa tradição, até 1850, a passagem pela Real Academia Militar não era importante, e sequer obrigatória para a formação da oficialidade. Muitos dos que ingressaram no corpo de oficiais generais na década de 1840 , por exemplo, não passaram pelas salas da Academia. ${ }^{67}$ 
Desse modo, o pai do jovem Osório tinha razão: em tempo de agitação política e num país em que não havia mestres, não havia profissão mais gloriosa do que a militar. E, para ser bem-sucedido nesta, não era preciso estudos, o que valia era ser fiel servidor da monarquia. Esse ensinamento, as duas famílias - tanto os Lima quanto os Osório - conheciam bem. Cada uma a sua maneira, percorrendo caminhos distintos, já haviam colhido vantagens com a prestação de serviços militares. Nas terras de fronteira, Manoel Luís da Silva Borges, descendente de uma humilde família de lavradores açorianos, entrando para as milícias, conseguiu tornar-se proprietário de terras e gado. Já na corte imperial, através do engajamento da família no Exército, servindo à Coroa em diferentes capitanias, José Joaquim de Lima tornou-se nobre e posicionou seus descendentes.

Na hierarquia do Exército, Manoel Luís Osório e Luiz Alves de Lima achavam-se em 1823 em pé de igualdade: o primeiro, mais moço, era alferes, e os 5 anos de idade a mais do segundo lhe rendeu o posto de tenente. Mas esta igualdade de condiçōes era só aparente. Como o ingresso no corpo de oficiais do Exército Real não significava ingressar em uma corporação moderna que, por meio da educação, se preocupasse em promover algum nível de homogeneização desses jovens, ainda que fosse uma ação voltada apenas para a formação militar, ${ }^{68}$ as diferenças sociais da vida pregressa desses jovens oficiais não só seguiam com eles, como formatavam suas carreiras no Exército, o que, neste caso específico, favoreceu enormemente ao tenente Luiz Alves de Lima.

Ao ingressar na Real Academia Militar, Luiz Alves pretendia seguir a arma de sua família, a de infantaria. Para isso, cumpriu os dois anos básicos do curso, exigidos pelo currículo. Mas ao encerrar o 20 ano, decidiu prosseguir seus estudos, cursando mais um ano da Academia. Em 1822, chegou a se matricular no $4^{\circ}$ ano, mas desistiu. ${ }^{69}$

É quase certo que tenha abandonado o curso em função da agitação política que tomava conta da cidade desde o retorno de D. João a Portugal no ano anterior, quando a independência já parecia inevitável. Pela experiência da família, Luiz Alves sabia que uma mudança como a que se anunciava era suficiente para modificar - positiva ou negativamente - a trajetória militar de cada um dos Lima, sobretudo dos mais jovens, que ainda tinham uma carreira por construir. A Real Academia Militar nessa época funcionava num prédio no Largo de São Francisco de Paula (atual Instituto de Filosofia e Ciências Sociais da UFRJ) e a agitação política inaugurada com as discussões sobre a volta da família real para Portugal tomava as praças do centro da cidade. O Largo do Rocio (atual Praça Tiradentes), atrás da Academia, era um dos palcos centrais dessas agitações e, por favorecer a aglomeração popular, sofreu intervenção e permaneceu ocupado por tropas até o dia 26 de abril, dia da partida de D. João VI. Menos de dois meses depois, no dia 5 de junho, o Rocio era mais uma vez tomado pela tropa - agora de corpos portugueses - para que D. Pedro jurasse a Constituição recém-publicada. ${ }^{70}$

Esse era sem dúvida um momento-chave da história do Império e, presentes ou não nas praças públicas, os Lima não ignoravam esses episódios. Os levantes de rua levavam D. Pedro a se aproximar da oficialidade e, ao mostrar habilidade para ocupar as praças e se valer da tropa em momentos de tensão, o príncipe firmava sua imagem como chefe militar, selando uma aliança com a oficialidade. ${ }^{71}$ Declarada a independência, essa aliança ganhou contorno mais nítido. Alguns oficiais do Exército voltaram para Lisboa, e a perspectiva para os que apoiaram D. Pedro não podia ser melhor. Além de terem sua posição assegurada, poderiam, com a abertura de vagas aos círculos hierárquicos mais baixos, ascender na carreira. A subida de D. Pedro ao trono - e a instabilidade política que ela gerava - configurava, assim, um momento ideal para a prestação de serviços e demonstraçôes de fidelidade à Coroa. Os Lima já tinham experiência o bastante para não desperdiçar a oportunidade. Todos se engajaram na defesa da Coroa, combatendo os que resistiam ao poder do Rio de Janeiro, fossem eles portugueses recolonizadores, ou grupos locais, que, logo após a dissolução da Assembleia Constituinte, em novembro de 1823, começavam a resistir à política do jovem imperador, considerada arbitrária.

Em 1823, Luiz Alves era ainda um jovem oficial, só em agosto completaria 20 anos. Todavia, com as relações familiares que possuía, viveu nesses anos uma sequência de experiências intensas, que foram 
sem dúvida fundamentais em sua formação como militar. Em janeiro, deixou o Regimento dos Lima para assumir o posto de tenente em um batalhão especial, o Batalhão do Imperador. Criado por decreto de 18 desse mês, o batalhão - de acordo com a lei - era a prova do quanto D. Pedro estava empenhado em proporcionar meios de livrar a Bahia da opressão das tropas portuguesas e do quanto ele buscava renovar os sentimentos patrióticos de seu povo pela causa do Brasil. ${ }^{72}$

Assim, ainda que em sua origem o Batalhão do Imperador estivesse vinculado a um episódio específico, a segunda parte do decreto de sua criação destaca uma função simbólica mais geral: o batalhão só poderia renovar os sentimentos patrióticos de seu povo pela causa do Brasil porque representava o Imperador. Em cada lugarejo por onde passava, o Batalhão do Imperador deveria deixar registrada a presença de D. Pedro e sua intenção de expulsar os portugueses e assegurar a unidade territorial, assim como cada manifestação de apoio da população e de autoridades locais à tropa também deveria ser entendida como uma forma de adesão à monarquia sediada no Rio de Janeiro. ${ }^{73}$

O critério usado por D. Pedro I para escolher o oficial que exerceria o comando do Batalhão do Imperador não é mencionado na lei, mas este recaiu sobre um Lima, José Joaquim de Lima e Silva, um dos tios de Luiz Alves, a quem ele serviu na Bahia como ajudante de ordens. Mas este não foi o único vínculo familiar do tenente Lima na campanha. No mesmo batalhão, Luiz Alves contou com o apoio de dois outros tios. Um deles era o tenente-coronel Manoel da Fonseca de Lima e Silva, a quem Luiz Alves estava subordinado, e o outro era o caçula dos irmãos Lima. João Manoel de Lima era mais novo que o sobrinho, e tornou-se um bom companheiro de armas. Mas isso não era tudo. A família ainda possuía enraizamentos fora do Rio de Janeiro.

Quando, em fevereiro, o Batalhão do Imperador chegou a Maceió - porto mais próximo da Bahia que não havia sido ocupado pelos portugueses - o comandante José Joaquim de Lima redigiu algumas proclamações e mandou que seu ajudante de ordens, o tenente Luiz Alves de Lima, as entregasse ao comandante de armas da província para que fossem distribuídas pelas povoações. Essas proclamaçóes tentavam evitar conflitos desnecessários e, desse modo, garantir que a viagem da tropa por terra fosse tranquila. Os documentos faziam uma apresentação do batalhão e do trajeto que ele cumpriria no interior da província. Porém, quando o tenente Lima, na função de ajudante de ordens, se dirigiu ao comandante de armas para entregar-lhe as proclamaçoes encontrou, na verdade, um de seus tios maternos, Joaquim Mariano de Oliveira Belo. Ele era, à época, comandante de armas de Alagoas. Os laços de parentesco, ampliados e tecidos entre famílias de um mesmo ofício, podiam favorecer a implantação de políticas de governo e, nesse caso específico, potencializavam o desempenho de comissões militares. ${ }^{74}$

Expedições desse tipo eram sempre cercadas por dificuldades. Oficiais estranhos à região, representantes de um poder distante e na maior parte do tempo ausente, de uma hora para outra passavam a integrar comunidades políticas que não conheciam, e pior, assumindo postos de comando. Essa posição, propriamente intervencionista, exigia dos oficiais sensibilidade política. Aliás, esse deve ter sido o maior aprendizado do tenente Luiz Alves na Bahia. Se José Joaquim em Alagoas colheu louros por onde passava, a realidade que o Batalhão do Imperador encontrou em Cachoeira - centro da articulação das forças do Recôncavo - era outra, bastante complexa e hostil. ${ }^{75}$

Não é o lugar aqui para abordar detalhes da ação do Batalhão do Imperador na Bahia, mas vale destacar que os dez meses de campanha foram marcados por sucessivos golpes, que envolviam alianças e conflitos entre políticos, militares locais e militares da corte, numa intrincada trama política. O coronel José Joaquim de Lima ocupou posição de destaque em todos esses golpes, ora sendo beneficiado, e conseguindo com a simples patente de coronel se tornar "comandante em chefe do Exército e de todas as tropas de $1^{\underline{a}}$ e $2^{\underline{a}}$ linha, no exercício de todas quantas atribuiçốes competiam ao ex-general e brigadeiro Pedro Labatut", ora sendo perseguido e obrigado a deixar a região. ${ }^{76}$

O tenente Luiz Alves de Lima presenciou todas essas disputas e golpes político-militares e, na posição de ajudante de ordens, participou intensivamente de todos eles. Sua assinatura consta na ata de todas as reuniôes realizadas pelo comandante Lima com a oficialidade durante esses conflitos. ${ }^{77}$ Era sua primeira 
campanha militar e, retornando ao Rio de Janeiro, viu o imperador abrir o cofre de suas graças e remunerar os serviços da família. José Joaquim de Lima, em fevereiro de 1824, foi nomeado ajudante de campo do imperador, Dignitário da Ordem do Cruzeiro e alçado ao grupo de oficiais generais, sendo promovido a brigadeiro. Ainda nesse mesmo mês, seu irmão, Manoel da Fonseca de Lima, foi efetivado no posto de tenente-coronel do Batalhão do Imperador e condecorado Oficial da Ordem do Cruzeiro. João Manoel de Lima, caçula dos irmãos Lima, recebeu a patente de tenente, e Luiz Alves a patente de capitão. ${ }^{78}$

Apenas seis meses após essa ampla remuneração, no dia 1ํㅡㄹ de agosto, Francisco de Lima embarcou para o Nordeste, com destino a Pernambuco. O jovem imperador, como prova da confiança que vinha depositando nos Lima, decidiu enviar o brigadeiro como general comandante de todas as forças imperiais na repressão à Confederação do Equador. ${ }^{79}$ No entanto, dessa expedição, Luiz Alves não participou. Depois da Bahia, o capitão só voltou a integrar uma expedição militar em junho de 1825, quando partiu em direção ao sul, para lutar numa guerra externa e se envolver nos conflitos tão familiares aos rio-grandenses - os combates pela posse da Província da Cisplatina.

Sobre a participação de Luiz Alves de Lima na guerra, não foi possível localizar material expressivo. Levando em conta o tempo que o capitão permaneceu na região, de três anos, é difícil não perguntar qual o lugar dessa experiência em sua formação. Mas talvez o próprio peso militar da campanha, que mobilizou um grande contingente naval e terrestre, tenha contribuído para diluir a presença do Batalhão do Imperador - unidade militar de Luiz Alves - na guerra e, posteriormente, nos livros de memória. ${ }^{80}$

Ainda que a eclosão da guerra date de 10 de dezembro de 1825, os conflitos de fronteira eram uma constante na vida dos habitantes do Rio Grande. Desde a declaração de Independência do Império do Brasil, e a expulsão do general Lecor de Montevidéu pelas tropas portuguesas de D. Álvaro da Costa, até novembro de 1823, por exemplo, a região esteve em franca disputa. Foi exatamente em função desses últimos conflitos, em torno do reconhecimento da independência, que o pai de Manoel Luís Osório decidiu levá-lo para assentar praça nas milícias, e também foi por conta dessa mobilização que, um ano depois, o rapaz conseguiu passar ao Exército com o título de cadete. Um esforço que se explicava também pelo interesse na rica zona pastoril da Província Oriental.

Desse modo, é preciso tentar olhar esses conflitos de fronteira de um ponto de vista local, menos vinculado aos interesses estratégicos do Rio de Janeiro. Para além das guerras oficiais, como a "Guerra da Cisplatina”, ou mesmo no interior dessas guerras, havia um conjunto de interesses e personagens outros, vinculados a disputas específicas, que constituíam o campo de possibilidades e de ação dos militares da fronteira. ${ }^{81}$

Se em junho de 1825, Luiz Alves de Lima se engajava em uma nova expedição militar, que anunciava o início de mais uma guerra, para Manoel Luís Osório a guerra era cotidiana, e a novidade agora ficava por conta apenas da interferência mais decisiva do Rio de Janeiro nos conflitos. Desde 1811, quando a independência de Buenos Aires precipitou uma aliança entre o governador de Montevidéu, fiel à Espanha, e a Coroa portuguesa para conter o projeto de libertação da região do Prata, a Província Oriental começou a ser devastada por revoluções e contrarrevoluçôes. ${ }^{82} \mathrm{O}$ fim da campanha não pôs fim à ação das cavalarias milicianas do Rio Grande e de algumas tropas enviadas pelo governo do Rio de Janeiro, e que permaneceriam na região. Até 1816, quando os conflitos voltaram a envolver de forma direta o Rio de Janeiro, as "correrias" - usando uma expressão dos contemporâneos - persistiram. ${ }^{83}$ Por isso, talvez, Manoel Luís da Silva Borges tenha desconsiderado as lágrimas do filho e o levado para assentar praça. A vida na região, tanto a econômica quanto a política, nessas primeiras décadas do XIX, só existia em meio aos conflitos. Daí a ideia de uma cultura do "soldado-estancieiro", ou - ainda segundo Spencer Leitman - uma cultura das "terras de fronteira". ${ }^{84}$

As notícias sobre a atuação do alferes Manoel Luís Osório nessas campanhas, tal como as de Luiz Alves de Lima, são escassas. Ambos eram bem jovens, Manoel Luís tinha apenas 17 anos de idade. Seu filho e biógrafo, Fernando Luís Osório, afirma que não localizou documentos que o ajudassem a contar a vida do oficial nesses anos. E, por isso, decidiu realizar breves entrevistas. Elaborou perguntas que o pai, o então marechal do Exército e marquês de Herval, devia responder. $\mathrm{O}$ material é rico e, se o analisamos como ar- 
tefato memorialista, é possível afirmar que a imagem mais forte desses anos não é a da guerra sob comando de grandes chefes militares, enviados pelo Rio de Janeiro. A lembrança recuperada por Osório, ao fim de sua vida, é a dos duros combates contra os "célebres gaúchos", arregimentados por "guerreiros do Prata" como - ainda citando o biógrafo - Juan Antonio Lavalleja, Diego Rivera e Carlos Maria de Alvear. ${ }^{85}$

É claro que nessa narrativa, como em qualquer construção memorialista, há uma montagem que silencia e destaca, através de um processo seletivo, fatos, feitos e nomes. No caso, é importante destacar que o acesso ao depoimento do então general Osório se dá através da narrativa do neto, dos recortes que fez e apresentou ao leitor. Mas, mesmo assim, ela nos auxilia deslocar a história desses conflitos do centro, da corte do Rio de Janeiro, para a região, para as províncias do Rio Grande e da Cisplatina. Os "primeiros contendores" de Manoel Luís Osório - de acordo com seu filho - foram esses "célebres gaúchos" ${ }^{86}$ Esses homens são descritos como tipos que, ao lado de índios indômitos e do gado selvagem, erravam pelos pampas. Violentos, viviam e lutavam em cima de seus cavalos, um inimigo móvel que manejava a lança e o laço com extrema destreza. ${ }^{87}$

Não foi por acaso que o biógrafo se deteve no tema. Sua intenção era apresentar ao leitor a escola em que se formara Manoel Luís Osório. Ele aborda o tema após narrar com detalhes um episódio da famosa batalha de Sarandi, ocorrida em outubro de 1825 e que levou D. Pedro I a formalizar a declaração de guerra contra as Províncias Unidas do Prata. Nela o alferes Manoel Luís teria se destacado não só por ter escapado, mas por ter matado dois "cavaleiros gaúchos" que o perseguiam. Seu merecimento e bravura seriam meses depois atestados, através de documentos oficiais, por dois de seus superiores: o coronel Bento Manoel Ribeiro e o tenente-coronel Felipe Neri de Oliveira. ${ }^{88}$

Para Fernando Osório, o filho-biógrafo, os "livros nem sempre eram exatos" e, para um militar, mais valia a experiência. Manoel Luís Osório "recebeu suas primeiras lições práticas de estratégia militar e da ciência do comando", sendo bem comandado, por "chefes de grande patriotismo", e lutando contra "hábeis contendores". Foi ainda nesta escola que aprendeu "a topografia do território Oriental e do Rio Grande do Sul, cruzando estes campos, "calcando-os debaixo das patas de seu cavalo". Era ela também que lhe daria "conhecimento da índole, usos e costumes dos povos vizinhos". ${ }^{89}$

O perfil de militar desenhado era, portanto, o do "tarimbeiro", aquele que se faz nos combates, com a prática, adquirindo experiência. Neste sentido, e mais uma vez, as trajetórias de Luiz Alves de Lima e Manoel Luís Osório se assemelham. Apesar de ter cursado a Real Academia Militar, não foi nos bancos escolares que Luiz Alves aprendeu o ofício. Também aprendeu na prática, à moda dos tarimbeiros. Mas esse aprendizado não incluía apenas lições de guerra: esses jovens, ao circularem entre tantos militares e autoridades políticas de prestígio, aprendiam também a negociar. Esse era um atributo fundamental para um militar do século XIX. Se na Bahia, Luiz Alves acompanhou sucessivos golpes políticomilitares e, na posição de ajudante de ordens, ajudou seu tio, o coronel José Joaquim de Lima, na articulação de alianças, Manoel Luís, na Província Oriental, também passou por experiência semelhante. Durante a Guerra da Cisplatina, quando se tentou tratar de acordos de paz, os comandantes Lavalleja, Diego Rivera e o general Lecor trocaram entre eles, como era comum, diversos ofícios. Esses documentos eram enviados por meio de portadores, que eram também negociadores. Por diversas vezes, Manoel Luís acompanhou esses oficiais, e cativou de tal maneira os comandantes orientais, que, ao final da guerra, estes solicitaram ao general Lecor permissão para que o oficial passasse oito dias com eles no Serro Largo. Autorizado, o agora tenente Osório teve a honra - segundo seu biógrafo - de ser hospedado pelo próprio Lavalleja. ${ }^{90}$

Mas se as experiências dos dois oficiais pareciam semelhantes, na hierarquia do Exército, Luiz Alves começava a se distinguir. Terminada a guerra, em 1828, o jovem Lima foi promovido a sargento-mor do prestigioso Batalhão do Imperador, ingressando no círculo de oficiais superiores, e ainda recebeu duas condecorações: nesse mesmo ano foi agraciado com a da Ordem de São Bento de Aviz e, no ano seguinte, em 1829, com a de Cavaleiro da Ordem da Rosa. ${ }^{91}$ Enquanto isso, o alferes Manoel Luís Osório era promovido a tenente, sem distinções. Claramente, a inserção política da rede social dos Lima, sobretudo suas vinculações na corte do primeiro imperador, interferia no destino do oficial. Mas não é 
apenas isso. Aproveitando as oportunidades, as novas gerações da família conseguiram reproduzir, no Império do Brasil, o modelo consagrado no velho continente. Eles se constituíam como oficiais do Império, aceitando comissões fora do Rio de Janeiro e, com isso, circulando entre províncias convulsionadas. A tarefa seguia sendo bem remunerada pela Coroa, e a família Lima se destacava aos olhos de D. Pedro I. Em contrapartida, Manoel Luís Osório, por mais brilhante que fosse, era um oficial das "terras de fronteira", e, como tal, seu campo de possibilidades era mais estreito.

\section{Experiência, configuração e trajetória}

Nos dias que precederam ao 7 de abril de 1831, a agitação política tomava mais uma vez as ruas e praças da corte imperial. Aquele imperador de 1822, político sensível, que cativava a oficialidade com sua capacidade de ocupar as praças, mostrava-se desde a Confederação do Equador inteiramente inábil para gerir conflitos políticos. Do antigo chefe militar, posição que lhe era garantida pelo direito dinástico, restavam apenas os descomedidos atos de força. ${ }^{92}$ Atos que, aliás, atingiram de forma certeira o mais velho dos Lima, Francisco de Lima. Na repressão aos pernambucanos, em 1824, o brigadeiro Lima, discordando das ordens de D. Pedro, tentou negociá-las e adiou seu cumprimento. Por agir de forma tão independente quase perdeu o cargo e, quando retornou à corte, mesmo trazendo a vitória sobre os confederados, sofreu uma série de desconsiderações, não recebendo qualquer promoção e, inclusive, sendo afastado do Rio de Janeiro.

Mas até as resistências de Francisco de Lima, ao final, acabaram se revertendo favoravelmente à família. Com a crise instituída, nos últimos anos da década de 1820, o brigadeiro Lima foi transformado pelos oposicionistas em símbolo maior da "tirania" do imperador, e de sua preferência pelos portugueses. Assim, quando ocorre a abdicação, o prestígio de Francisco de Lima se estende à família, que passa a ocupar os principais postos político e militares do Império. No próprio dia 7 de abril, o brigadeiro foi eleito para a Regência Trina Provisória e, dois meses depois, foi o nome mais votado para a Regência Trina Permanente. Seu irmão, o brigadeiro José Joaquim de Lima, até então ajudante de campo de D. Pedro I, assumiu o Comando de Armas da Corte e, logo em seguida, outro dos irmãos Lima, Manoel da Fonseca de Lima, antes no comando do Batalhão do Imperador, assumiu nada menos que o Ministério da Guerra.

Não é intenção desse artigo acompanhar Luiz Alves de Lima e Manoel Luís Osório até seus últimos dias: ele se encerra quando o jovem Lima, aos 27 anos de idade, vê seu pai assumir a direção política do Império e dois tios seus, a direção militar. Sem desmerecer a ação e qualidades individuais de Luiz Alves - já detalhadamente descritas em outra ocasião - é certo que o oficial era um homem de sorte. O reposicionamento da família, que seguiu um percurso nada linear, absolutamente sujeito às contingências do mundo da política, o colocou numa posição excepcional. $\mathrm{O}$ oficial que na década anterior, circulando pelas províncias, aprendeu a defender o princípio monárquico de uma Coroa sediada no Rio de Janeiro, ao mergulhar - como ocorreu nesses anos - nos conflitos que tomavam as ruas da corte, descobriu a importância de preservar um outro elemento herdado dos tempos coloniais: o sistema de hierarquias sociais assentado na escravidão. Após um longo "estágio" de sete anos na corte imperial, como comandante da Guarda de Municipais Permanentes, que equivalia à atual polícia militar, o oficial voltaria a integrar expedições militares, só que na posição de comandante. Foi nessas circunstâncias que, em outubro de 1842, embarcou para o Rio Grande do Sul.

Quando chegou a Porto Alegre, Luiz Alves de Lima já era um oficial experiente, e muito bem posicionado. Tendo comandado a repressão aos balaios no Maranhão e aos liberais de São Paulo e Minas, voltava à capital gaúcha, depois de 14 anos, no posto de marechal de campo, e investido comandante em chefe das forças em operações no Rio Grande do Sul e presidente da província. Além disso, era agora nobre: barão de Caxias.

Não demorou muito para o barão conhecer Manoel Luís Osório. Este oficial não havia aderido ao exército farroupilha e, com todo conhecimento que tinha da província, logo se transformou num no- 
me importante para as forças imperiais. Mas a discrepância é desconcertante. Só naquele ano, de 1842, Manoel Luís Osório havia sido promovido a sargento-mor (atual major). Pela patente de capitão, esperou por 11 anos. Assim como a trajetória de Luiz Alves de Lima foi alavancada pelos acontecimentos de 7 de abril, a de Osório, com a falta de guerras na região e de uma rede de relações com ramificações no Rio de Janeiro, seguiu um ritmo lento. Segundo o filho-biógrafo, o então tenente Osório foi esquecido, destacado para um serviço "enfadonho", servindo na fronteira. ${ }^{93}$

Dois militares, e duas trajetórias tão distintas. A história de Manoel Luís Osório só começa a mudar quando justamente serve sob o comando do barão de Caxias. Ao fim da Farroupilha, o oficial foi promovido a tenente-coronel, nomeado Cavaleiro da Ordem de São Bento de Aviz e, atendendo a um pedido do barão, se candidatou à eleição de 1845, sendo eleito deputado provincial. Para Caxias, que se tornava conde, a aliança era interessante e, em outros momentos, políticos ou militares, ele voltaria a acionar esses vínculos regionais. Já Manoel Luís Osório ganhava um amigo na corte imperial.

Discrepâncias como estas, no entanto, só eram possíveis pelo predomínio de um modelo de Exército aberto, cuja estrutura e formas de organização seguiam um sistema de valores que eram os da sociedade política. Por isso também, metodologicamente, a substituição das tipologias e prosopografias pela análise de trajetórias de vida pode, nesse caso, se tornar um recurso valioso. A experiência é do campo do individual, do particular e do inimitável. Em vez de enfatizar as formas de homogeneidade social, ela póe em relevo a heterogeneidade que, em toda sociedade, prevalece quando se trata de distribuição de recursos, materiais ou simbólicos. Manoel Luís Osório e Luiz Alves de Lima agiam em função de uma situação que lhes era própria, absolutamente singular.

Para compreender o comportamento de cada um deles, é preciso levar em conta sua posição particular no interior de uma rede social. Como explica Norbert Elias, todo indivíduo ocupa um lugar em uma teia humana composta por relações que não lhe é permitido modificar senão dentro de certos limites. Desse modo, escrever um trabalho a partir de trajetórias de vida é, em parte, pensar essas relações que se precipitam sobre os indivíduos no momento do nascimento e através das quais eles se colocam no mundo. ${ }^{94}$ Daí o conceito de configuração. Ele expressa essa rede de dependências de forma plástica, como inter-relações em constante adaptação. ${ }^{95}$ Os lugares por onde Luiz Alves de Lima e Manoel Luís Osório circularam, o modo como agiam em relação às pessoas e o que decidiam, lhe permitiam dar continuidade, reelaborar ou romper com relações herdadas, além de lhe dar a chance de tecer novas alianças sociais.

Foi nesse jogo relacional que procurei - ainda que de forma limitada - inscrever e pensar a trajetória dos dois oficiais, tentando sujeitá-las inclusive às contingências da experiência. $\mathrm{O}$ resultado de uma ação individual depende de outras ações e das reações de outros indivíduos. Essa dependência, própria do mundo social, impede que os atores contem com um sistema de normas para tentar prever ou evitar os efeitos de seus atos. Ainda que cada indivíduo tenha diante de si um campo de possibilidades limitado, com margens definidas cultural e socialmente, nenhum sistema normativo é suficientemente estruturado para eliminar todas as possibilidades de escolha, interpretação, manipulação e negociação das regras sociais. ${ }^{96}$ Por isso também é que, transformado em uma brecha de acesso ao passado, uma trajetória nos permite pensar questões mais gerais, relativas a relaçôes familiares, à formação e a estratégias de socialização e de ação no mundo.

\section{Notas}

${ }^{1}$ GINZBURG, Carlo. O Queijo e os Vermes: o cotidiano e as ideias de um moleiro perseguido pela Inquisição. São Paulo, Companhia das Letras, 1987, p. 27 (grifo meu).

${ }^{2}$ Hoje contamos com ótimas reflexões sobre o biográfico na historiografia, dentre eles, cito dois textos clássicos: LEVI, Giovanni. Usos da biografia In: FERREIRA, Marieta de Moraes, AMADO, Janaina (Org.). Usos \& abusos da História Oral. Rio de Janeiro, Editora Fundação Getúlio Vargas, 1998; e LORIGA, Sabina. A biografia como problema. In: REVEL, Jacques. Jogos de escalas: a experiência da microanálise. Rio de Janeiro, Fundação Getúlio Vargas, 1998. 
3 SOUZA, Adriana Barreto de. Duque de Caxias: o homem por trás do monumento. Rio de Janeiro, Civilização Brasileira, 2008. Ver especialmente a introdução do livro.

${ }^{4}$ GINZBURG, Carlo. A Micro-História e Outros Ensaios. Rio de Janeiro, Bertrand Brasil, 1989.

${ }^{5}$ A referência aqui é GINZBURG, Carlo. Sinais. Raízes de um paradigma indiciário. In: Carlo Ginzburg. Mitos, Emblemas, Sinais: morfologia e história. São Paulo, Companhia das Letras, 1989. Destaco também uma importante crítica a este texto, realizada pelo antropólogo DIDI-HUBERMAN, George. "Pour une anthropologie des singularités formelles. Remarque sur l'invention warburgienne”. Genèses. Sciences Sociales et Histoire, 24 septembre, 1996, p. 145-156.

${ }^{6}$ GINZBURG, Carlo. O queijo e os vermes. Op. cit., p. 26.

${ }^{7}$ Ver especialmente o texto de Hubert Bonin em Problèmes et méthodes de la biographie, Actes du Colloque, Sorbonne, 3-4 mai 1985 , n⿳o esp. de Sources.

${ }^{8}$ SOUZA, Adriana Barreto de. O Exército na consolidação do Império: um estudo histórico sobre a política militar conservadora. Rio de Janeiro, Arquivo Nacional, 1999.

${ }^{9}$ SOUZA, Adriana Barreto de. A serviço de Sua Majestade: a tradição militar portuguesa na composição do generalato brasileiro (1837-1850). In: Nova História Militar Brasileira. Castro, Celso, Vítor Izecksohn, e Hendrik Kraay (Org.). Rio de Janeiro: FGV/ Bom texto, 2004.

${ }^{10}$ No texto acima referido, proponho um esboço de tipologia para pensar, ainda que de forma bem geral, possíveis modelos de carreira militar na primeira metade do XIX. Idem, p. 171.

${ }^{11}$ Essa crítica foi construída a partir de um diálogo estreito com pesquisas da chamada Micro-história. Destaco, em especial, as reflexões teórico-metodológicas de Simona Cerutti e Maurizio Gribaudi sobre a construção do social a partir de redes de relações egocentradas. Ver as referências na bibliografia.

${ }^{12}$ A trajetória do general Osório ainda não foi objeto de trabalho mais circunstanciado. Mas sua memória tem sido revisitada a partir do interesse pela memória do duque de Caxias, e pelo que Celso Castro denominou "a invenção do Exército brasileiro". No primeiro caso, ver SOUZA, Adriana Barreto de. "Osório e Caxias: a memória militar que a república manda guardar”. In: Varia História. no 25. Belo Horizonte, UFBH, julho de 2001, p. 231-251. Para o segundo, ver: CASTRO, Celso. A invenção do Exército brasileiro. Rio de Janeiro, Jorge Zahar Editor, 2002. A biografia em questão é OSÓRIO, Fernando Luís. História do General Osório. Rio de Janeiro, Talagarça: Fundação Trompowsky, 2008.

${ }^{13}$ SILVA, Andrée Mansuy-Diniz. Portugal e Brasil: a reorganização do Império, 1750-1808. In: BETHELL, Leslie. (Org.). História da América Latina. Vol. I. São Paulo: Edusp, 1996, p. 480. Para a definição da importância econômica do Brasil na preservação de Portugal, ver p. 477.

${ }^{14}$ BETHELL, Leslie. Op. cit., p. 480.

${ }^{15}$ Sobre as datas, ver: BRITO, Paulo José Miguel. Memória política sobre a capitania de Santa Catarina. Já para o número de açorianos, consultar: MAXWELL, Kenneth. Marquês de Pombal, paradoxo do Iluminismo. Rio de Janeiro, Paz e Terra, 1996, p. 134.

${ }^{16}$ Todas as informaçôes biográficas foram retiradas de OSÒRIO, Fernando Luís, Op. cit., p. 73-5.

${ }^{17}$ MAXWELL, Kenneth. Op. cit., p. 136.

${ }^{18}$ OSÒRIO, Fernando Luís. Op. cit., p. 75.

19 Idem. Ibidem.

${ }^{20}$ Idem., p. 80.

${ }^{21}$ Idem, p. 81 e 82.

${ }^{22}$ DONATO, Hernâni. Dicionário das batalhas brasileiras (Dos conflitos indígenas aos choques da reforma agrária). Rio de Janeiro: Bibliex Ed. São Paulo: IBRASA, 2001, p. 97.

${ }^{23}$ LIMA, Oliveira. D. João VI no Brasil. Rio de janeiro, Topbooks, 1996.

${ }^{24}$ OSÒRIO, Fernando Luís. Op. cit., p. 77.

${ }^{25}$ MAGALHÃES, João B. A evolução militar do Brasil. Rio de Janeiro, Biblioteca do Exército, 1998.

${ }^{26}$ SOUZA, Adriana Barreto de. Duque de Caxias: o homem por trás do monumento, p. 463.

${ }^{27}$ A formulação é de Spenser Leitman. LEITMAN, Spencer. Raízes sócio-econômicas da Guerra dos Farrapos. Rio de Janeiro, Ed. Graal, 1979, p. 79.

${ }^{28}$ OSÓRIO, Fernando Luís. Op. cit., p. 77.

${ }^{29}$ Os dois futuros líderes estrearam na vida militar, assim como o pai de Osório, na Campanha de 1810. Neste movimento, também adquiriram terras e gado. Ver os sítios www.paginadogaucho.com.br/pers/n-david-cana.htm e www.paginadogaucho.com.br/pers/n-bento-gonc.htm. 
${ }^{30}$ Apud MARQUÊS, Fernando Pereira. Exército e sociedade em Portugal. No declínio do antigo regime e advento do liberalismo. Lisboa, A Regra do Jogo, 1981, p. 36.

${ }^{31}$ Para detalhes da trajetória de Francisco de Lima da Silva, e da família em Portugal e no Brasil, ver: SOUZA, Adriana Barreto de. Duque de Caxias. Op. cit. Capítulo 1.

${ }^{32}$ Francisco Falcon, A Época Pombalina. Capítulo VI: A prática do Pombalismo. Sobre a criação do título de cadete, ver: COLEÇÃO das Leis, Alvarás e Decretos Militares, que desde o princípio do reinado do sr. rei d. José I se tem promulgado até o referente ano de 1791. Alvará de 16 de março de 1757.

33 Sobre a importância das patentes e mercês na estruturação de uma sociedade de Antigo Regime, organizada em torno de uma nobreza política. Ver: Nuno Gonçalo Monteiro, op. cit. Sobretudo cap. 1.

${ }^{34}$ Decretos do Conselho de Guerra de 10 de julho de 1777, maço 136, no 71.

${ }^{35}$ Para o óbito do brigadeiro, Registro Paroquial de Faro - Conselho de Castro Marim - Freguesia de Castro Marim: caixa 83, livro 8, data: 11 de outubro de 1779. ANTT.

${ }^{36}$ Sobre a carreira de José Joaquim de Lima da Silva, ver documento intitulado: "Relação das Idades, Antiguidades, Diferentes Graduações, Conduta, Préstimo dos Oficiais, Oficiais Inferiores e Cadetes do $1^{\circ}$ Regimento de Infantaria da Cidade do RJ”. Cota: h 7,3,50 - no 6. Setor de Manuscritos, BN.

${ }^{37} \mathrm{O}$ casamento é citado por DANTAS, Carlos e RHEINGANTZ, Carlos. Achegas genealógicas à ascendência de Luiz Alves de Lima e Silva, duque de Caxias. RJ, Colégio Brasileiro de Genealogia, s/d.

${ }^{38}$ Para as patentes da família Fonseca da Costa: DANTAS, Carlos, RHEINGANTZ, Carlos. op. cit. Força de linha é outro nome dado às forças regulares. Compunham o primeiro escalão das forças militares do Reino e eram as únicas sustentadas pela Coroa. Os terços auxiliares foram criados em 1645, quando passaram a ocupar o segundo escalão das tropas militares. Apesar de integrados também por paisanos, eram treinados e armados de modo a poder auxiliar prontamente as tropas regulares.

${ }^{39}$ Ver o processo: "Documentos avulsos - RJ", do AHU. Caixa 160, doc.88 - [ant. 1800, setembro, 27].

${ }^{40}$ A ideia vem sendo explorada na historiografia mais recente, sobretudo para analisar a trajetória de homens ligados ao comércio de grosso trato. Ver: João Fragoso, Maria Fernanda Bicalho e Maria de Fátima Gouvêa, O Antigo Regime nos trópicos. O caso mais famoso é o da família Carneiro Leão.

${ }^{41}$ Arquivo Geral de Mercês e Graças Honoríficas do ANRJ. Códice 137, livro 9, fl.107.

${ }^{42}$ LIMA, Oliveira. D. João VI no Brasil. Rio de janeiro, Topbooks, 1996, p. 285. Michael McBeth considera o período joanino uma fase privilegiada para os militares do Brasil, exatamente pela rapidez das promoções. Ver: Michael McBeth, Brazilian Generals, I822-I865, p. 129.

43 Sobre a expedição de José Joaquim de Lima ao Piauí, ver: SILVA, Alfredo Pretextato Maciel. Os generais do Exército Brasileiro de 1822 a 1889. Rio de Janeiro, Ed. Americana, 1906-1907. Entrada nominal. As promoçôes estão no Arquivo Geral de Mercês e Graças Honoríficas do ANRJ. Para José Joaquim: códice 137, livro 43, fl.28v, e para a de Francisco de Lima: códice 137 , livro 45 , fl.48.

${ }^{44}$ Essa tradição aparece em vários documentos. Ver, para Portugal, os "Documentos das Divisões" do AHM e, para o Rio de Janeiro, sobretudo o caso do "Regimento dos Lima": o códice 88 - "Correspondências do General e Comandante de Tropas do RJ” (1799-1805), depositado no ANRJ.

${ }^{45}$ Essas informaçōes constam no Arquivo Geral de Mercês e Graças Honoríficas do ANRJ. Ver respectivamente: códice: 15, livro 5, fl.158 e códice 137, livro 34, fl.28v.

${ }^{46}$ Um decreto baixado em 13 de maio de 1789 por D. Maria I garantia que "todos os oficiais militares que subirem aos postos de marechal de campo ou de tenente-general dos meus exércitos (...) sejam tomados logo por fidalgos da minha Casa Real, expedindo-lhes pela mordomia-mor os seus competentes alvarás sem dependência de outro algum requisito mais do que o da certeza de se acharem promovidos aos referidos postos." Coleção de Leis, Alvarás e decretos Militares, op. cit.

${ }^{47}$ Todos estes dados estão no Arquivo Geral de Mercês e Graças Honoríficas do ANRJ. O hábito de Cristo recebido por Manoel da Fonseca está registrado no códice 15, livro 5, fl.158; a vida na comenda de São Bento de Aviz está no códice 15, livro 7, fl.42 e o foro de fidalgo cavaleiro recebido por José Joaquim está no códice 137, livro 52, fl.133.

${ }^{48} \mathrm{O}$ conceito foi elaborado por Antônio Manuel de Hespanha para análise da sociedade portuguesa dos séculos XVII e XVIII e a ideia do enraizamento de uma cultura de Antigo Regime é de Maria de Fátima Gouvêa, ambos citados anteriormente.

${ }^{49}$ Folha de serviço de um militar onde consta dados pessoais e é registrada sua trajetória no Exército.

${ }^{50}$ AZEVEDO, Manuel Duarte Moreira de. “Os Túmulos de um Claustro”. RIHGB. T.29, parte 2, 1866.

${ }^{51}$ Sobre a família Oliveira Belo: SOUZA, Adriana Barreto. Duque de Caxias. Op. cit., p. 85-90.

${ }^{52}$ COLEÇÃO das Leis, Alvarás e Decretos Militares, que desde o princípio do reinado do sr. rei d. José I se tem promulgado até o referente ano de 1791. Alvará de 16 de março de 1757.

53 Sobre o funcionamento desta burocracia: SOUZA, Adriana Barreto de. Duque de Caxias, p. 56. 
${ }^{54}$ Dados retirados da Coleção de Leis, Alvarás e Decretos Militares. Alvará de 16 de março de 1757.

${ }^{55}$ As referências sobre a família continuam seguindo: OSÓRIO, Fernando Luís. Op. cit.

${ }^{56}$ Sobre este episódio da trajetória dos Osório na América portuguesa: Idem, p. 81-92.

${ }^{57}$ Idem, p. 106.

${ }^{58}$ Idem, p. 132.

${ }^{59}$ Idem, p. 134.

${ }^{60}$ Idem, p. 139-140.

${ }^{61}$ Idem, ibidem.

${ }^{62}$ Idem, p. 140.

${ }^{63}$ Os livros de matrícula da Academia se encontram depositados no AN - microfilme: 001-1-75.

${ }^{64}$ Gilberto Velho, Projeto e metamorfose. Rio de Janeiro, Jorge Zahar Editor, 1994.

${ }^{65} \mathrm{O}$ ofício dos oficiais acha-se no setor de manuscritos da BN. Cota: II-34, 25, 30.

${ }^{66}$ Sabina Loriga, Soldats, p. 108. A citação é uma tradução livre do francês.

${ }^{67}$ Adriana Barreto de Souza, O Exército na consolidação do Império. Op. cit. Capítulo I.

${ }^{68}$ Para o atual modelo de formação dos oficiais do Exército brasileiro, ver: CASTRO, Celso. O espirito militar: um estudo de antropologia social na Academia Militar das Agulhas Negras. Rio de Janeiro, Jorge Zahar Editor, 1990. A preocupação com a homogeneização é discutida no capítulo 1.

69 "Livro de Registro e Matrícula da Real Academia Militar (1811-1822)", do AN.

${ }^{70}$ Os fatos acima são narrados por NEVES, Lúcia Maria Bastos Pereira das. Corcundas e constitucionais. Rio de Janeiro, Revan: Faperj, 2003, p. 252-254 e por SOUZA, Iara Lis Carvalho. Pátria coroada: o Brasil como corpo politico autônomo (17801831). São Paulo, Unesp, 1999, p. 94-106.

${ }^{71}$ Iara Lis Carvalho Souza, op. cit. Sobre o Império do Brasil, p. 128 e para a imagem de D. Pedro, p. 174.

${ }^{72}$ Coleção de Leis do Brasil - decreto de 18 de janeiro de 1823.

73 SOUZA, Adriana Barreto de. Duque de Caxias. Op. cit. Capítulo 2.

${ }^{74}$ Fundo Ministério da Guerra - IG1 249. Ofício de 20 fev. 1823.

75 SOUZA, Adriana Barreto de. Duque de Caxias. Op. cit. Capítulo 2.

${ }^{76}$ Livro de Ordens do Dia do Batalhão do Imperador - códice 275, p. 32. Ordem de 27/05/1823.

${ }^{77}$ Fundo Ministério da Guerra - IG1 114. Anexo do ofício de 28 de maio 1823.

${ }^{78}$ Para José Joaquim de Lima e Silva, ver a Portaria de 17 de fevereiro de 1824 da Coleção de Leis do Brasil e o códice 15 livro 10, fl.73v do Arquivo Geral de Mercês e Graças Honoríficas. Nesse arquivo, está também a condecoração de Manoel da Fonseca - códice 15, livro 10, fl.73. A carta patente concedida a João Manoel de Lima está no Livro de Ordens do Dia do Batalhão do Imperador - códice 275, p. 195. Ordem do Dia de 18 fev. 1824.

${ }^{79}$ Essa campanha foi de extrema importância para os Lima, alterando inteiramente as relaçôes entre a família e o imperador. Detalhes em SOUZA, Adriana Barreto de. Duque de Caxias. Op. cit. Capítulo 2.

${ }^{80} \mathrm{Em}$ 1825, o Brasil já possuía uma esquadra numerosa no Rio da Prata. Tasso Fragoso chegou a dizer que se havia criado um "círculo de ferro" ao redor de Buenos Aires. Sobre as forças de terra, afirma que houve um "recrutamento geral e rigoroso". Ver: FRAGOSO, Tasso. A Batalha do Passo do Rosário. Rio de Janeiro, Biblioteca do Exército, 1951 , p. 186 e 209, respectivamente.

${ }^{81}$ Ver especialmente: LYNCH, John. As repúblicas do Prata da independência à Guerra do Paraguai. In: BETHELL, Leslie. (Org.). História da América Latina. V. III. São Paulo: EdUsp, 1996.

${ }^{82}$ Idem, p. 625.

${ }^{83}$ FRAGOSO, Tasso. A Batalha do Passo do Rosário. Rio de Janeiro, Biblioteca do Exército, 1951. Capítulo VIII da Primeira Parte e capítulo I da Segunda Parte.

${ }^{84}$ LEITMAN, Spencer. Raízes sócio-econômicas da Guerra dos Farrapos. Rio de Janeiro, Ed. Graal, 1979, p. 79.

${ }^{85}$ Esses depoimentos surgem no meio da narrativa, mas o autor comenta o uso dos mesmos no início do livro, na parte intitulada "Ao leitor". Ver: OSÓRIO, Fernando Luís, op. cit., p. 27.

${ }^{86}$ Idem, p. 200.

${ }^{87}$ A definição é de LYNCH, John. Op. cit., p. 639.

${ }^{88}$ Ver: OSÓRIO, Fernando Luís. Op. cit., p. 155.

${ }^{89}$ Idem, p. 201. 
${ }^{90}$ Idem, p. 198.

${ }^{91}$ SOUZA, Adriana Barreto de. Duque de Caxias. Op. cit. Anexo II.

${ }^{92}$ Iara Lis Carvalho de Souza. Op. cit., p. 174.

${ }^{93}$ Ver: OSÓRIO, Fernando Luís. Op. cit., p. 233.

${ }^{94}$ A referência para pensar a relação indivíduo-sociedade é ELIAS, Norbet. A sociedade dos indivíduos. Rio de Janeiro, Jorge Zahar Editor, 1994.

${ }^{55}$ GRIBAUDI, Maurizio. Espaces, temporalités, stratifications: exercices sur les réseaux sociaux. Paris, École des Hautes Études em Sciences Sociales, 1998.

96 "Campo de possibilidade" é utilizado por Gilberto Velho para analisar trajetórias e biografias. VELHO, Gilberto. Projeto e metamorfose: antropologia das sociedades complexas. Rio de Janeiro, Zahar, 1994.

\section{Referências bibliográficas}

CARVALHO, José Murilo de. A construção da ordem: a elite política imperial. Brasília: Editora da Universidade de Brasília, 1981.

CASTRO, Celso. O espirito militar: um estudo de antropologia social na Academia Militar das Agulhas Negras. Rio de Janeiro: Jorge Zahar Editor, 1990.

. A invenção do exército brasileiro. Rio de Janeiro: Jorge Zahar Editor, 2002.

CASTRO, Celso \& SOUZA, Adriana Barreto de. A defesa militar da Amazônia: entre história e memória. In: Celso Castro (Org.). Amazônia e defesa nacional. Rio de Janeiro: Editora Fundação Getúlio Vargas, 2006.

CERUTTI, Simona. Normes et pratiques, ou de la légitimité de leur opposition. In: LEPETIT, Bernard. Les formes de l'experience: une autre histoire sociale. Paris: Albin Michele, 1995.

. Processo e experiência: indivíduos, grupos e identidades em Turim no século XVII. In: REVEL, Jacques. Jogos de escalas: a experiência da microanálise. Rio de Janeiro: Editora da Fundação Getúlio Vargas, 1998.

COSTA, Fernando Dores. A nobreza é uma elite militar? O caso Castanhede-Marialva em 1658-1665. In: MONTEIRO, Nuno Gonçalo; CARDIM, Pedro \& CUNHA, Mafalda Soares da. Optima Pars. Elites ibero-americanas do Antigo Regime. Lisboa: ICS; Imprensa de Ciências Sociais, 2005.

. Milícia e sociedade. In: BARATA, Manuel Themudo \& TEIXEIRA, Nuno Severiano. História Militar de Portugal. Volume II. Lisboa: Círculo dos Leitores, 2004.

COSTA, João Pereira da. Memória sobre a utilidade da extinção de cadetes. Lisboa: Impr. Liberal, 1822.

COSTA, Veríssimo Antônio Ferreira da. Coleção sistemática das leis militares de Portugal. Lisboa: Impressão Régia, 1816.

DIDI-HUBERMAN, George. Pour une anthropologie des singularités formelles. Remarque sur l'invention warburgienne. Genèses. Sciences Sociales et Histoire, 24 septembre, 1996, p. 145-156.

DONATO, Hernâni. Dicionário das batalhas brasileiras. Dos conflitos indígenas aos choques da reforma agrária. Rio de Janeiro: Bibliex; Ed. São Paulo: IBRASA, 2001.

ELIAS, Norbert. A sociedade dos indivíduos. Rio de Janeiro: Jorge Zahar Editor, 1994.

. A sociedade de corte. Rio de Janeiro: Jorge Zahar Editor, 2001.

FALCON, Francisco José Calazans. A época pombalina: politica econômica e monarquia ilustrada. São Paulo: Ática, 1982.

FRAGOSO, João \& FLORENTINO, Manolo. O arcaísmo como projeto. Mercado Atlântico, sociedade agrária e elite mercantil no Rio de Janeiro (c.1790 - c.1840). Rio de Janeiro: Diadorim, 1993.

FRAGOSO, João; BICALHO, Maria Fernanda \& GOUVÊA, Maria de Fátima (Orgs.). O Antigo Regime nos trópicos: a dinâmica imperial portuguesa (séculos XVI-XVIII). Rio de Janeiro: Civilização Brasileira, 2001.

GEERTZ, Clifford. A interpretação das culturas. Rio de Janeiro: Zahar, 1978.

GINZBURG, Carlo. O queijo e os vermes: o cotidiano e as ideias de um moleiro perseguido pela Inquisição. São Paulo: Companhia das Letras, 1987.

. Mitos, emblemas, sinais: morfologia e história. São Paulo: Companhia das Letras, 1989. 
. A micro-história e outros ensaios. Rio de Janeiro: Bertrand Brasil, 1989.

GOFFMAN, Erving. Manicômios, prisões e conventos. São Paulo: Perspectiva, 1974.

GOUVÊA, Maria de Fátima Silva. Redes de poder na América portuguesa. O caso dos Homens Bons do Rio de Janeiro: 1790-1822. Revista Brasileira de História. São Paulo/Humanas Publicaçōes, v.18, no 36, 1998, p. 297-330.

GRIBAUDI, Maurizio. Itinéraires ouvriers: espaces et groupes sociaux à Turin au début du XXe. siècle. Paris: EHESS, 1987.

Espaces, temporalités, stratifications: exercices sur les réseaux sociaux. Paris: École des Hautes Études em Sciences Sociales, 1998.

. Escala, pertinência e configuração. In: REVEL, Jacques. Jogos de escalas: a experiência da microanálise. Rio de Janeiro: Editora da Fundação Getúlio Vargas, 1998.

GUIMARÃES, Manoel Luiz Salgado. Micro-História: reconstruindo o campo de possibilidades. Topoi, Rio de Janeiro: nำ1, 2000.

LEITMAN, Spencer. Raizes sócio-econômicas da Guerra dos Farrapos. Rio de Janeiro: Ed. Graal, 1979.

LEVI, Giovani. Le pouvoir au village: histoire d'un exorciste dans le Piémonte du XVIIe. Siècle. Paris: Gallimard, 1989.

Usos da biografia. In: FERREIRA, Marieta de Moraes \& AMADO, Janaina (Org.). Usos \& abusos da História Oral. Rio de Janeiro: Editora Fundação Getúlio Vargas, 1998.

LIMA, Oliveira. D. João VI no Brasil. Rio de Janeiro: Topbooks, 1996.

LORIGA, Sabina. Soldats, un laboratoire disciplinaire: l'armée piémontaise au XVIIIe. siècle. Paris: Mentha, 1991.

. A biografia como problema. In: REVEL, Jacques. Jogos de escalas: a experiência da microanálise. Rio de Janeiro: Fundação Getúlio Vargas, 1998.

MAGALHÃES, João B. A evolução militar do Brasil. Rio de Janeiro: Biblioteca do Exército, 1998.

MARQUES, Fernando Pereira. Exército e sociedade em Portugal. No declínio do antigo regime e advento do liberalismo. Lisboa: A Regra do Jogo, 1981.

MATTOS, Ilmar Rohloff de. O tempo saquarema: a formação do Estado imperial. São Paulo: Hucitec, 1990.

MAXWELL, Kenneth. Marquês de Pombal, paradoxo do Iluminismo. Rio de Janeiro: Paz e Terra, 1996.

MCBETH, Michael Charles. The politicians vs. the generals: the decline os the brazilian Army during the First Empire, 1822-1831. Ph. D. diss., University of Washington, 1972.

MONTEIRO. Nuno Gonçalo. O crepuisculo dos Grandes (1750-1832). Lisboa: Imprensa Nacional da Casa da Moeda, 1998.

MONTEIRO, Nuno Gonçalo; CARDIM, Pedro \& CUNHA, Mafalda Soares da. Optima Pars. Elites ibero-americanas do Antigo Regime. Lisboa: ICS; Imprensa de Ciências Sociais, 2005.

NEVES, Lúcia Maria Bastos Pereira das. Corcundas e constitucionais: a cultura politica da independência (18201822). Rio de Janeiro: Revan; Faperj, 2003.

OSÓRIO, Fernando Luís. História do general Osório, v. 1 e 2. Pelotas: Tip. do Diário Popular, 1915.

POLLAK, Michael. Memória, esquecimento, silêncio. Estudos Históricos. Rio de Janeiro: 3: 3-15, 1989.

RIBEIRO, Gladys Sabina. A liberdade em construção: identidade nacional e conflitos antilusitanos no Primeiro Reinado. Rio de Janeiro: Relume-Dumará; Faperj, 2002.

SILVA, Andrée Mansuy-Diniz. Portugal e Brasil: a reorganização do Império, 1750-1808. In: BETHELL, Leslie (Org.). História da América Latina. V. I. São Paulo: EdUsp, 1996.

SOUZA, Adriana Barreto de. O Exército na consolidação do Império: um estudo histórico sobre a política militar conservadora. Rio de Janeiro: Arquivo Nacional, 1999.

. Duque de Caxias: o homem por trás do monumento. Rio de Janeiro: Civilização Brasileira, 2008.

. A serviço de Sua Majestade: a tradição militar portuguesa na composição do generalato brasileiro (1837-

1850). In: CASTRO, Celso; IZECKSOHN, Vítor \& KRAAY, Hendrik. (Org.). Nova História Militar Brasileira. Rio de Janeiro: FGV/ Bom texto, 2004.

. Osório e Caxias: a memória militar que a república manda guardar. Varia História. no 25. Belo Horizonte: UFBH, julho de 2001, p. 231-251. 


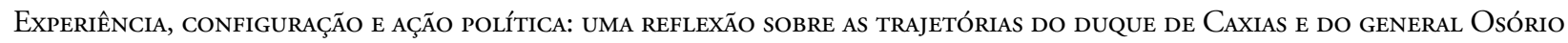
Adriana Barreto de Souza

SOUZA, Iara Lis Carvalho. Pátria coroada: o Brasil como corpo politico autônomo (1780-1831). São Paulo: Unesp, 1999.

VELHO, Gilberto. Projeto e metamorfose. Antropologia das sociedades complexas. Rio de Janeiro: Jorge Zahar Editor, 1994.

VELHO, Gilberto \& KUSCHNIR, Karina. Mediação, cultura e política. Rio de Janeiro: Aeroplano, 2001.

\section{RESUMO}

O objetivo desse artigo é realizar uma análise comparada das trajetórias do General Osório e do Duque de Caxias pa$r a$, através dela, investigar diferentes experiências institucionais, ou, se preferirmos, outras formas de ser militar no Brasil do século XIX.

Palavras-chave: duque de Caxias, general Osório, século XIX, Brasil.

\section{ABSTRACT}

This article intends to analyze and compare the trajectories of the General Osorio and the Duke of Caxias in order to investigate the different institutional experiences or, in other words, the diverse manners of "being military" in Brazil during the XIXth century.

Keywords: Duke of Caxias, General Osório, 19th century, Brazil. 